University of Louisville

ThinkIR: The University of Louisville's Institutional Repository

Electronic Theses and Dissertations

$12-2006$

\title{
Physical and biological control of zooplankton in the Ohio River.
}

Tamara Dawn Sluss

University of Louisville

Follow this and additional works at: https://ir.library.louisville.edu/etd

\section{Recommended Citation}

Sluss, Tamara Dawn, "Physical and biological control of zooplankton in the Ohio River." (2006). Electronic Theses and Dissertations. Paper 1344.

https://doi.org/10.18297/etd/1344

This Doctoral Dissertation is brought to you for free and open access by ThinkIR: The University of Louisville's Institutional Repository. It has been accepted for inclusion in Electronic Theses and Dissertations by an authorized administrator of ThinkIR: The University of Louisville's Institutional Repository. This title appears here courtesy of the author, who has retained all other copyrights. For more information, please contact thinkir@louisville.edu. 


\title{
PHYSICAL AND BIOLOGICAL CONTROL OF ZOOPLANKTON IN THE OHIO
} RIVER

\section{By}

Tamara Dawn Sluss

B.S., University of Louisville, 2000

M.S., University of Louisville, 2003

\author{
A Dissertation \\ Submitted to the Faculty of the \\ Graduate School of the University of Louisville \\ In Partial Fulfillment of the Requirements \\ For the Degree of
}

Doctor of Philosophy

Department of Biology

University of Louisville

Louisville, Kentucky

December, 2006 
Copyright 2006 by Tamara D. Sluss

All rights reserved 
PHYSICAL AND BIOLOGICAL CONTROL OF ZOOPLANKTON IN THE OHIO RIVER

\author{
By
}

Tamara Dawn Sluss

B.S., University of Louisville, 2000

M.S., University of Louisville, 2003

A Dissertation Approved on

August 2006

By the following Dissertation Committee:

$\overline{\text { Dissertation Director }}$ 


\section{ACKNOWLEDGEMENTS}

I would like to acknowledge the fact that Dr. Jeffrey Jack has been an excellent mentor. He understands the balance of freedom and support in the role of a mentor. I would also like to show my appreciation for my other committee members: Dr. Jim Alexander, Dr. Perri Eason, Dr. Margeret Carreiro, and Dr. Mark French. I have had the pleasure of being a student in most of their classes and their comments have greatly improved my dissertation. Dr. Gary Cobbs played an integral role in the design and analysis of experimental portion of this dissertation. I would also like to thank Gina Bergner, Jaime Coomes, Stacy

Pritchard, Tara Trammell, and Dale McGaha for their help in the field and lab and Debbie Guelda for her zooplankton legacy. This dissertation is dedicated to my parents Mike and Gloria Sluss, my little family, Justin and Olivia Jean Elkins, and my surrogate family, John and Judy Elkins for their patience and support for as long as they have known me. 


\begin{abstract}
PHYSICAL AND BIOLOGICAL CONTROL OF ZOOPLANKTON IN THE OHIO RIVER

Tamara D. Sluss

December, 2006
\end{abstract}

This dissertation explores the physical and biological factors that control zooplankton population growth rates in the Ohio River (USA). I employed both observational studies and a mesocosm experiment to ascertain zooplankton population and community dynamics in response to biotic and abiotic variables. This dissertation is separated into three chapters. In chapter 1 , I introduce the reader to life history traits of zooplankton and characteristics of large rivers. In chapter 2, I present the results of an observational study of zooplankton population growth rates in two navigation pools of the Ohio River and use multiple regression analysis to determine the significance of environmental variables on zooplankton taxa densities and population growth rates. In addition, I use ordination analysis to assess zooplankton community similarity and spatial positioning among sites in the Ohio River and two tributaries, the Wabash and Kentucky Rivers. In the final chapter I test the effect of velocity on zooplankton communities and their impact on chlorophyll $\alpha$ and particulate organic carbon. My results provide a mechanistic explanation for the observed patterns of 
zooplankton in the Ohio River and how river management may affect these important members of riverine food webs. 
TABLE OF CONTENTS

PAGE

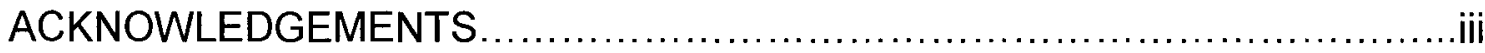

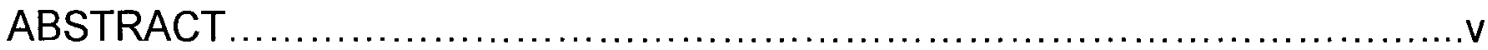

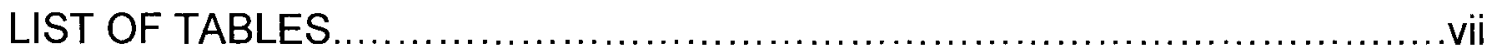

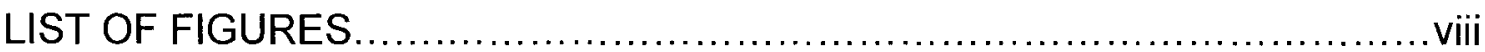

CHAPTER

I. THE ZOOPLANKTON OF LARGE RIVERS $\ldots \ldots \ldots \ldots \ldots \ldots \ldots \ldots$

II. ZOOPLANKTON IN LARGE RIVERS: POPULATION GROWTH RATES AND COMMUNITY ASSEMBLAGES IN RELATION TO ENVIRONMENTAL FACTORS AND VARIATION IN RIVERINE HABITAT .........................................................

III. THE IMPACT OF WATER COLUMN VELOCITY ON THE GRAZING AND COMMUNITY DYNAMICS OF OHIO RIVER ZOOPLANKTON: A MESOCOSM EXPERIMENT.

REFERENCES. 74

CURRICULUM VITAE 84 


\section{LIST OF TABLES}

TABLE

PAGE

1. Population growth rate results of river surveys ..........................56

2. Ordination results of 2002 river surveys ................................57

3. Ordination results of river surveys by groups and date ...................58

4. ANOVA results of velocity on population growth rates....................59

5. ANOVA results for POC in velocity experiments......................60

6. ANOVA results for chlorophyll $\alpha$ in velocity experiments.................61 


\section{LIST OF FIGURES}

FIGURE

PAGE

1. The Ohio River and the McAlpine and Smithland Pools

2. Discharge in the McAlpine and Smithland Pools in 2001 and 2002

3. Mean total zooplankton densities in the McAlpine and Smithland Pools.

4. Zooplankton population growth rates in the McAlpine and Smithland Pool...64

5. POC in the McAlpine and Smithland Pools in 2001 and 2002 .65

6. Turbidity in the McAlpine and Smithland Pools in 2001 and 2002 66

7. Chlorophyll in the McAlpine and Smithland Pools in 2001 and 2002. 67

8. Tank design for velocity experiment. 68

9. Zooplankton densities in April and August velocity experiments 69

10. Population growth rates of dominant zooplankton taxa throughout velocity experiment

11. POC in April and August velocity experiments.

12. Whole chlorophyll in April and August velocity experiments. .72 


\section{CHAPTER I \\ THE ZOOPLANKTON OF LARGE RIVERS}

INTRODUCTION

Lotic (flowing water) systems range from intermittent streams to the great rivers. Along this continuum, there are similarities and differences in the chemical, physical, and biological characteristics of these habitats. However, one factor common to all lotic environments, and one that distinguishes these systems from lentic habitats, is unidirectional water flow.

Moving water, with its direct and indirect effects on the resident organisms, is a "master variable" that heavily influences the physical and biotic environment of lotic systems. For example, lentic habitats often exhibit varying degrees of thermal stratification, while flow-induced mixing in lotic systems largely prevents this phenomenon and simultaneously can increase turbidity in the water column. There are also differences among the lotic systems driven by the interactions of water volume and geomorphology. Lower order, high-gradient streams are often shaded, have pool-riffle sequences, narrow channels and coarser substrates, while larger rivers are often more turbid, with a flow regime 
that is less variable with finer sediments and limited light penetration (Vannote et al. 1980).

There have been several attempts to develop explanatory models for how the interaction of biological and physical processes in lotic systems produces the unique communities associated with particular reaches of these systems. The River Continuum Concept (RCC) proposed an orderly progression of community assemblages, chemical, physical parameters, and carbon sources for lotic systems from small streams to large rivers (Vannote et al. 1980). The Flood Pulse Concept (FPC, Junk and Bayly 1989) theorized that a majority of river carbon was allochthonous in origin and was only accessed during greater than bank-full events. Recently, the Riverine Productivity Model (RPM) developed by Thorp et al. (1998) proposed that phytoplankton production, although it was quantitatively a small percentage of the available carbon in rivers, was a significant source of carbon and food for grazers because of its comparatively high quality. All of these models sought to explain the changes in communities and in carbon sources, but differed in the importance placed on autochthonous carbon; that is, carbon fixed by processes within the stream as opposed to terrestrially-derived carbon being loaded off the watershed. The RCC and FPC minimized the importance of autochthonous production in the main channel of a large river, while the RPM suggested that the quality of the autochthonous carbon may compensate for its low quantity in river systems. 
While these models have sought to explain large-scale processes such as carbon fate and sources in rivers, there has been less emphasis on the community and population-level interactions among riverine organisms, with the possible exception of research in large river fisheries and mussel populations. For example, the behavior and ecology of zooplankton in lakes has been widely studied across the globe since the pioneering work of Forbes and others in the late 1800 s, but river zooplankton have been little studied until recently (Hynes 1979). Zooplankton are found from in all most lotic systems, from intermittent streams (Brown et al. 1989) to great rivers (Thorp et al. 1994), from the main channel to near-shore slack waters (Spaink et al. 1998), and in flood plain lakes (Basu et al. 2000). Rotifers, cladocera, and copepods are the most studied members of the river zooplankton community, perhaps because of their relatively large size and relative ease of identification; protists are rarely included in studies of zooplankton in rivers (but see Kobayashi et al. 1998).

There has recently been more interest in the zooplankton of rivers and their ecological roles in these unique lotic habitats (e.g. Thorp et al. 1994, Basu and Pick 1996 and 1997, Gosselain et al. 1998, Viroux 1997, 1999, and 2002). In some river systems, the zooplankton seem to be important primary consumers, analogous to their role in many lakes (Williamson 1987). For example, Gosselain et al. (1998) found that zooplankton were responsible for late summer declines in phytoplankton populations in some European rivers, while in a study of two Australian rivers, the zooplankton community impacted a small 
portion of phytoplankton year round (Kobayashi et al. 1996). In turn, zooplankton in rivers are fed upon by a variety of secondary consumers such as fish (e.g. Jack and Thorp 2002), insect larvae, and mussels (Thorp and Casper 2004). The seasonal and temporal dynamics of lacustrine zooplankton have been examined in many lake systems, but similar studies on zooplankton in large rivers are relatively rare. Some investigators have suggested that riverine zooplankton communities are "naturally" dominated by rotifers and small cladocera (e.g. Shiel et al. 1982; Viroux 2002) but do not suggest a mechanism to explain their dominance. In a comparison of riverine zooplankton community assemblages with those of the Great Lakes, Guelda (2001) reported that there were comparatively higher densities of copepods in the lake communities than in the Ohio River and several of its large tributaries.

Given their roles as predators and prey in lotic food webs, factors that limit zooplankton densities or which affect zooplankton community structure and temporal dynamics may have significant effects on ecosystem level processes in large rivers. There are a number of physical and biotic features of lotic systems that may have a pronounced effect on riverine zooplankton population growth. Physical parameters such as discharge or water residence times have been shown to be an important controlling factor of zooplankton densities in many rivers (Baranyi et al. 2002, Pace et al. 1992, Basu and Pick 1996, Jackson et al. 1991). Abiotic factors associated with the hydrograph in rivers include turbidity, discharge, current velocity, light penetration, nutrients, temperature, and dissolved oxygen, but the relative strengths among these factors in structuring 
zooplankton communities are relatively unknown. The hydrology of lotic systems is dynamic and influences zooplankton in a variety of ways. The flow of water downstream in lotic systems may cause advective loss when transit times are too fast in a river reach to allow sufficient zooplankton population growth to replace losses (Pace et al. 1992). In a study of 31 rivers in Ontario, Canada, Basu and Pick (1996) discovered that overall zooplankton biomass was positively related to the water residence time. Increased discharge during a flooding event in the Red River and Lake Texoma diminished zooplankton abundance (Dirnberger and Threlkeld 1986) except for Moina and Diaphanasoma whose populations increased (Threlkeld 1986). Viroux (2002) also found that high discharge events significantly influenced zooplankton structure in the River Meuse via greater negative effects on cladocerans than copepods. Seasonal changes in discharge may influence zooplankton successional patterns at the community level as well. Baranyi et al. (2002) and Keckeis et al. (2003) found that river zooplankton communities in the Danube River shifted from rotifer domination to cladocerans and copepods when water residence times increased during the growing season. In my review of forty papers of studies involving the study of zooplankton in large rivers, I determined that discharge, velocity, water level, or water residence time were cited as significant factors in $75 \%$ of the studies.

While advective loss is perhaps the most obvious negative effect of elevated discharge on zooplankton, changes in hydrology may influence zooplankton via other mechanisms as well. Elevated discharge may enhance mineral turbidity and velocity in the water column of large rivers. High mineral 
turbidity may directly alter foraging ability and cause feeding interference or physical damage, as has been shown in lake zooplankton communities (Kirk and Gilbert 1990, Jack et al. 1993, Akopian et al. 1999). Indirectly, high turbidity levels may decrease light penetration into the water column, which may already limit algae in many large rivers such as the Ohio (Sellers and Bukaveckas 2003). Elevated discharge may also increase turbulence in rivers. While turbulence effects on zooplankton have been studied in marine systems, to my knowledge they have not been assessed in large rivers.

There is also evidence that biotic interactions can influence riverine zooplankton population growth rates, and thus community structure (e.g. Pace et al. 1988, Jack and Thorp 2002, Thorp and Casper 2004; Guelda et al. 2005). Biotic mechanisms such as predation and competition, that can be important in regulating zooplankton communities in lakes, may also be operating in riverine communities, although there are comparatively few experimental studies designed to test the importance of such mechanisms in rivers. The potential for "bottom-up" control of riverine zooplankton population growth depends on the quantity and quality of food available in their environment (e.g. Sterner et al. 1993, Rothhaupt 1995, DeMott et al. 1998, MacKay and Elser 1998, DeMott and Gulati 1999). Zooplankton may be food-limited in a number of ways. For example, if food resources in a river are present in low concentrations or are of low quality (such as seston with low phosphorus levels or with associated toxins), population growth rates of zooplankton may be reduced. Conversely, when food is superabundant, feeding rates may be reduced or physiological rates raised via 
feeding interference (e.g. Porter et al. 1982). Unfortunately, compared to lakes, little is known about the effect of seston quality on zooplankton in large rivers. In one study, zooplankton densities in 31 Canadian rivers were positively correlated to chlorophyll $\alpha$, a measure of algal abundance (Basu and Pick 1996). These studies suggest that zooplankton may be food-limited in at least some river systems. Guelda et al. (2005) conducted a series of mesocosm experiments in which they altered the densities of two common river zooplankton, Bosmina longirostris and cyclopoid copepods, under ambient or enriched food conditions, to assess the possibility that river zooplankton were food limited. They found that zooplankton growth rates varied directly with $\mathrm{POC}$ and chlorophyll $\alpha$ concentrations over a range of concentrations similar to those in the Ohio River and that algal carbon concentration was a good predictor for the population growth rate of Bosmina. Their research suggested that zooplankton growth in the Ohio River could be limited by the availability of autochthonous carbon regardless of the concentrations of the more abundant but presumably more recalcitrant, allochthonous carbon, consistent with the predictions of the Riverine Productivity Model (Thorp et al. 1998).

There have also been recent studies linking the "performance" of zooplankton with the quality of river seston. In a laboratory study, Acharya et al. (2005) found that Bosmina grew faster and showed higher fecundity on laboratory-cultured Scenedesmus acutus than on river seston. In another study, Acharya et al (2006) showed that Bosmina growth rates were lower on river seston collected during elevated river discharge because of P-limitation and 
elevated allochthonous carbon loading; when discharges were low the seston Pconcentrations were higher and no longer limited Bosmina growth.

There may also be biotic controls in effect when zooplankton are introduced into rivers from adjacent lentic areas, such as marginal wetlands or floodplain lakes. Such effects seem to be transitory in most instances, presumably because the flow conditions and other environmental factors are not suitable to the maintenance of these populations. For example, in a study by Walks and Cyr (2004) the biomass of zooplankton introduced into a river from a lake outlet began to decrease significantly within $50 \mathrm{~m}$ of the point of introduction. Densities of large zooplankton such as cladocera and copepods dropped upon introduction to a river from reservoirs in both the Marne (France) and the Blue Nile (Pourriot et al. 1988, Talling and Rzoska 1967). Basu and Pick (2002) observed that densities of zooplankton exported from Lake Ontario into the St. Lawrence River also decreased rapidly as the communities moved downstream. Alternatively, some studies have shown that rotifers can maintain relatively high densities in rivers after release from upstream reservoirs (Jackson et al. 1991, Pourriot et al. 1997). The effects and fate of zooplankton introduced into rivers from smaller tributaries is nearly unstudied (but see the work of Guelda below). However, these sources may be important if the zooplankton entering the large river have been growing successfully in the smaller river.

Finally, the major groups of riverine zooplankton have very different life histories that can affect their responses to both biotic and abiotic factors in rivers. For example, copepods are sexual and are considered strong swimmers 
(Richardson 1992). Their ability to affect their three-dimensional position in a turbulent environment could be an advantage in riverine environments (Jack et al., in press). While rivers are considered well-mixed, there are slack water and shoreline areas where flows are lower and where food resources may be easier to obtain or where they may avoid potential predators

Cladocerans have reproductive features, such as parthenogenicity and diapausing eggs, that would seem advantageous in the adverse conditions that may be encountered in large rivers. Cladocera can also feed on a wide range of food types in the 1-25 $\mu \mathrm{m}$ range (Hall et al. 1976), such as bacteria, ciliates, rotifers, and phytoplankton (Lampert 1987b, Porter et al. 1983, Porter 1973, Burns and Gilbert 1986, Dodson 1975, Peters and Downing 1984). Despite this apparent flexibility, most riverine cladocerans are present in relatively low densities compared to cladocerans in lakes (Shiel et al. 1982, Guelda 2001). Cladocera are known to be negatively affected by turbidity and velocity (Richardson 1992), which can be important physical forces in lotic environments. However, one genus of cladocerans, Bosmina, is commonly found in lotic systems (Viroux 1997). Bosmina are capable of selecting between a wide range of particles (DeMott and Kerfoot 1982, DeMott 1986). This may give Bosmina an advantage in feeding in turbulent and turbid river conditions, where much of the carbon may be of low quality and mixed with suspended mineral particles.

Rotifers are the smallest members of the metazoan zooplankton community and also have the shortest generation times. They have a relatively low starvation threshold (Wallace and Snell 1991, Gilbert 1985a), are usually 
parthenogenic and can lay diapausing eggs. They are capable of feeding almost continuously in turbulent environments (Kirk and Gilbert 1990) and these characteristics may explain why this group is so common in rivers, particularly during high flow periods.

Human management of these systems may also influence the relative importance of biotic and abiotic impacts on zooplankton growth rates and zooplankton community structure in rivers. The effects of river regulation by dams, weirs and other regulation structures vary, but they generally influence zooplankton communities through their effects on water retention. For example, a $156 \mathrm{~km}$ regulated reach of the Meuse had more large crustaceans than the lower Rhine because of increased water residence times created by weirs (de Ruyter van Steveninck et al. 1990). Higher zooplankton densities in the downstream Nakdong River (Korea) were attributed to an estuary dam (Kim and Joo 2000). In low-head dam systems, such as those associated with navigation locks, the impact on river function is different than that of "high head" reservoir dams. There have been few studies of the effects of low head dams on river systems; Pillard and Anderson (1993) found that zooplankton densities in Pool 19 of the regulated Upper Mississippi River were greater upstream during high flow and greater downstream at low flow periods. They also found higher zooplankton densities at the lower, more lacustrine reach of the pool. River regulation may also decrease zooplankton abundance and diversity by decreasing habitat heterogeneity (Viroux 1997). 


\section{Previous Ohio River Research}

The Ohio River (Figure 1) is the second largest river in the United States by discharge (Thorp et al. 1994). On the main stem Ohio River, there are 21 "low-head" navigation dams, which divide the river into "navigation pools". The channel characteristics (mean depth, slope, etc.) and the management of the dams greatly influence certain physical properties of these pools (light penetration levels, residence times, etc.) that can have important implications for the zooplankton (e.g. Shiel et al. 1982, Pillard and Anderson 1993). In addition, the river has a number of large tributaries (the Kentucky, the Green, the Wabash, the Cumberland and the Tennessee Rivers) in its lower reaches which could have important effects on the zooplankton communities.

Despite the tremendous importance of this river ecologically and economically, and the potential importance of the zooplankton to the river fishery, there have been few plankton studies on the Ohio River until recently. Brinley and Katzin (1942) analyzed a series of plankton collections in the main stem Ohio and its tributaries, including the Cumberland, Green and Kentucky Rivers, in 1939 and 1940. They found few differences in the distribution of phytoplankton species among sites from along the length of the main stem, although they did note that areas with "high organic inputs" in the form of urban sewage did support higher densities of phytoplankton. Williams (1966), in his survey of the rotifers of the US, noted that for most rivers the plankton was dominated by one genus/species, although the particular genus/species varied from river to river. In the Ohio, Williams found that Keratella was the most 
common rotifer genus reported in the 1961-62 US Public Health Surveys. He also noted that rotifer densities tended to be positively correlated with periods of "high clarity and low velocity" and that the densities of rotifers at the Ohio River stations tended to be lower than those found in other rivers such as the Mississippi and Illinois.

Thorp et al. (1994) and Wehr and Thorp (1997) conducted the first recent assessment of the zooplankton and phytoplankton (respectively) of the lower Ohio River. In a year-long survey, Thorp et al. 1994 reported that zooplankton densities followed seasonal patterns, being lower in the high discharge/high turbidity periods and higher during high temperature periods; however, they did not find any significant diversity patterns linked with their measured physical variables. The zooplankton was numerically dominated by rotifers, particularly in the tributaries. By comparing zooplankton densities just upstream and downstream of low-head navigation dams in the Ohio River, they did not find that the dams had any effect on zooplankton. In the phytoplankton survey, Wehr and Thorp found that phytoplankton densities were significantly correlated with temperature and current velocities, although a decline in picoplankton numbers across pools was associated with an increase in copepod nauplii densities. Nutrient concentrations had no significant effect on phytoplankton communities, but benthic diatom forms tended to disappear from the plankton in the slackwater areas near the navigation dams. These surveys were followed by the work of Sellers and Bukaveckas (2003) and Bukaveckas et al. (2005), which examined the McAlpine Pool and the lower $600 \mathrm{~km}$ of the river (respectively) from an 
ecosystem-process perspective. In the former study, the authors used a stagedischarge model to link light availability with navigation pool-wide estimates of phytoplankton production. They found that light availability was a strong and significant predictor of phytoplankton production throughout most of the year, although the model overestimated chlorophyll $\alpha$ production in the late growing season. Light conditions in the shallower, upper part of the McAlpine navigation pool were much more conducive to phytoplankton growth than conditions in the deeper, lower section of the pool. Thus phytoplankton production in the upper portion of the McAlpine Pool could be lost via respiration in the lower section, limiting resources for the resident zooplankton. This work provided a mechanistic basis for many of the observations of Wehr and Thorp (1997) linking phytoplankton densities with physical conditions in the river. Although grazing on zooplankton was not a significant determinant in the model, it may have explained the discrepancy in the predicted and observed late summer chlorophyll $\alpha$ values.

Bukaveckas and his colleagues also took a mass-balance approach to assessing the fate of chlorophyll $\alpha$, dissolved organic carbon (DOC) and inorganic nitrogen along the lower main stem and tributaries of the Ohio River. This reach of the river was found to be a source for the former two and a sink for the latter (Bukaveckas et al 2005.).

In addition to these large-scale surveys, there were several smaller-scale observational and experimental projects on the lower river, particularly in the McAlpine Pool. Two experiments using large volume in situ mesocosms 
("potamocorrals") in the Ohio River demonstrated that zebra mussels (Dreissena polymorpha) (Jack and Thorp 2001) and larval fish (Jack and Thorp 2002) could individually and in combination decrease the growth rates of some zooplankton taxa via direct "top down" impacts such as predation. The fish predators negatively affected population growth rates of the copepod Diacyclops and the cladoceran Diaphanasoma but indirectly increased the growth rates of the small rotifer Polyarthra. To my knowledge, there have been no other published studies assessing the importance of predation on Ohio River zooplankton, although there are data suggesting that some zooplankton may alter their three-dimensional position in the river to avoid fish predation (Jack et al., in press).

\section{Research Questions}

The experimental work to date suggests that food limitation may be an important factor limiting zooplankton population growth rates in the Ohio River. However, the field studies that had been performed either did not assess population growth rate responses (e.g. Williams 1966, Thorp et al 1994) or employed a very limited number of sampling events (e.g. Guelda, unpublished data). I used observational studies over a two-year period to determine the effect of environmental variables such as discharge, chlorophyll $\alpha$ concentrations, turbidity, and particulate organic carbon (POC) on zooplankton population growth rates in the McAlpine and Smithland navigation pools of the Ohio River. I hypothesized that growth rates would be positively correlated with food resources such as chlorophyll $\alpha$ and POC and negatively affected by turbidity and 
discharge. Because navigation dams alter the habitats of rivers by creating more lacustrine conditions in upstream reaches of a pool, I hypothesized that zooplankton community assemblages in these habitats would differ from communities in more riverine habitats in the downstream reach within the same pool. I also expected that there could be differences between the zooplankton responses between the two pools because of the differences in their geomorphic characteristics.

I also assessed a heretofore-unstudied aspect of the riverine environment, velocity, on zooplankton population growth. While the effects of turbulence on marine zooplankton are relatively well studied (see Chapter III), hydrological factors have not been assessed experimentally in river systems. I developed a new experimental approach using a mesocosm system to assess the impact of velocity on zooplankton community dynamics and herbivory. By manipulating grazer presence and velocity over a two-week period, I examined the growth responses of a spring and fall Ohio River zooplankton community to velocity and the responses of their potential food resources, such as phytoplankton to differing levels of grazing and velocity. I hypothesized that the spring zooplankton communities would be able to graze effectively under high or low levels of velocity, but that the cladoceran-dominated fall community would not be able to graze effectively under the high velocity conditions. If these hypothesized effects were to be significant, this would be the first mechanistic evidence for the role of velocity in structuring a freshwater zooplankton community. 
Both of these studies would provide important insights into the role of zooplankton in large river systems and the effects of human management of these important ecological systems. There has been increased interest in the zooplankton communities in large rivers because of their roles as consumers and for their possible utility as bioindicators of river condition (e.g. the USEPA Great Rivers EMAP program). Knowledge of the zooplankton community and how river modifications affect zooplankton will be critical to successful management of species such as the paddle fish (Polydon spathula) and perhaps the unionid mussel fauna. There are also concerns about nutrient loads in many large river systems and the resultant algal blooms that can give rise to taste, odor or disinfection byproduct problems for drinking water systems drawing form the river (Jack et al. 2002). As primary consumers, river zooplankton may have important effects on phytoplankton blooms. The role of zooplankton in responding to changes in phytoplankton needs to be understood if we are to improve the predictive capacity of river autotrophic production models (e.g. Sellers and Bukaveckas 2003). Thus, this work may both improve our understanding of the role of zooplankton in riverine food webs and contribute to the development of better management strategies for large river systems. 
CHAPTER II

ZOOPLANKTON IN LARGE RIVERS: THE EFFECTS OF

ENVIRONMENTAL FACTORS AND RIVERINE HABITAT ON POPULATION GROWTH RATES AND COMMUNITY ASSEMBLAGES

\section{INTRODUCTION}

Zooplankton play important roles in aquatic habitats as primary and secondary consumers (Williamson 1987) and there is a large body of literature showing their importance in energy and material transfers from phytoplankton, bacteria, and detritus to higher trophic levels in these systems (e.g. Mallin and Paerl 1994; Chapter I). Given their potential impacts in river communities, factors that limit zooplankton densities or that affect zooplankton community structure may have significant effects on food webs in large rivers such as the Ohio River (USA).

Physical parameters such discharge or water residence times have been shown to be important controlling factors of zooplankton densities in many rivers (Baranyi et al. 2002, Pace et al. 1992, Basu and Pick 1996, Jackson et al. 1991). Abiotic factors associated with peaks in the hydrograph of large rivers include 
increased turbidity, current velocity, nutrients, dissolved oxygen, and temperature and decreased light penetration. However, the relative strengths among these factors in structuring zooplankton communities are relatively unknown. Biotic mechanisms such as predation and competition which can be important in regulating zooplankton communities in lakes may also be operating in riverine communities, although there are comparatively few experimental studies designed to test the importance of such mechanisms in these systems (see Chapter I for a review of the current literature).

To assess the relative importance of biological and physical factors in influencing zooplankton population growth rates in the Ohio River, I conducted a series of surveys over the length of the McAlpine Pool (119 kilometers) from late spring through fall 2001 and 2002 and the Smithland Pool in 2002 (118 kilometers). These periods are those of greatest zooplankton production in the river (Thorp et al. 1994). My objectives were to evaluate the relationships between multiple environmental variables and zooplankton population growth rates, to assess whether zooplankton productivity is internal (in the Ohio River pools I studied) or due to upstream production, to determine whether different zooplankton taxa respond differently to the effects of discharge, and to determine if the differential population growth responses can bring about a change in zooplankton community composition at downstream sites. To investigate these questions, I calculated pool-specific population growth rates for zooplankton taxa and analyzed these parameters using regression and ordination analysis.

Positive pool-specific population growth rates indicate internal production, but 
negative values represent upstream or tributary sources. Slopes of linear equations determined the sensitivity of each zooplankton taxon to discharge and other potentially significant environmental variables based on slope direction and value. I hypothesized that zooplankton population growth rates would be negatively correlated to pool discharge and turbidity, but positively correlated to mean pool chlorophyll a concentrations, and to particulate organic carbon (POC). I compared zooplankton communities between the two navigation pools and I also investigated similarities between upstream reaches and downstream reaches within each pool.

\section{METHODS}

This study was conducted in the McAlpine and Smithland navigation pools of the Ohio River, USA (Figure 1). I established four sampling locations for each pool: an upstream site, a site within the major tributary, a mid-pool site below the tributary confluence, and a downstream site. The McAlpine pool is a $119 \mathrm{~km}$ reach between the Markland and McAlpine Dams outside of Louisville, Kentucky and has one major tributary, the Kentucky River, which flows northward into the pool with a mean annual discharge of $239 \mathrm{~m}^{3} \mathrm{~s}^{-1}$. Vevay, Indiana (Ohio River Kilometer [ORK] 866), $10 \mathrm{~km}$ downstream from the Markland Dam served as the upstream site. There was also a site $1 \mathrm{~km}$ upstream in the Kentucky River, a mid-pool site at Westport, Kentucky (ORK 933) and a downstream site at Louisville, Kentucky (ORK965), approximately $11 \mathrm{~km}$ upstream from the McAlpine Dam at the base of the pool. 
The Smithland Pool is located between the J.T. Meyers Dam (ORK 1362) and the Smithland Lock and Dam (ORK 1479) and is approximately $117 \mathrm{~km}$ in length. Samples sites were collected at an upstream site $1 \mathrm{~km}$ below the J.T. Meyers Dam (ORK 1362) a mid-pool site at Cave in Rock, Illinois (ORK 1418), and the downstream site at Birdsville, KY (ORK 1471), and about $1 \mathrm{~km}$ upstream in the Wabash River, the major tributary to the Smithland pool that joins the Ohio River from the north at ORK 1365.

The Smithland Pool of the Ohio River is very similar in length to the McAlpine Pool. However, the Wabash River, contributes a greater volume of water ( $\approx 40-60 \%$ of the discharge of the Ohio River) to the main stem at its confluence than the Kentucky River does to the McAlpine ( $\approx 7 \%$ )of the discharge of the Ohio River. The channel of the McAlpine Pool is shallower than the Smithland Pool and may experience greater light penetration and more algal resources. Thus, these pools provide potentially interesting cross-pool as well as within pool contrasts due to differences in navigation dam effects.

\section{Sampling}

In 2001-2002, the McAlpine Pool was surveyed nine times while both the McAlpine and Smithland Pools were surveyed four times. Sampling was conducted in a semi-Lagrangian manner within each pool (Sellers 2001); that is I attempted to sample the same parcel of water as it passed through the length of the pools, beginning with the McAlpine Pool. Replicate samples (3-5) of 20 liters were collected from the main channel using a manual diaphragm pump at a 
depth of one meter. All samples in the Kentucky and Wabash Rivers were taken at least $1 \mathrm{~km}$ upstream from its confluence with the Ohio River to avoid potential mixing effects with the Ohio River. Samples were filtered through a 63 and 20 $\mu \mathrm{m}$ plankton net to capture the macrozooplankton and the rotifers, respectively. Zooplankton were narcotized with $\mathrm{CO}_{2}$ and were fixed with sugared formalin (Haney and Hall 1973). Ancillary readings of pH, specific conductance, dissolved oxygen, dissolved oxygen saturation, and temperature were also taken at the same sites using a Hydrolab Sonde 4a Water Quality Multiprobe (Hach Corp., Lowell, CO, USA). Water samples were collected and analyzed for turbidity, dissolved nutrients (ammonia, nitrate, orthophosphorus, and silica), chlorophyll $\alpha$, and POC.

\section{Lab Analysis}

Particulate organic carbon in water samples was determined by the ash free dry mass method and sample turbidity was assessed using a Hach turbidometer (Hach Corp., Lowell, CO, USA, 1200 A). Chlorophyll $\alpha$, an indicator of algal abundance, was cold-extracted with acetone and measured using fluoroscopic methods with a Turner 10-AU Fluorometer based on U.S. EPA standard methods 445.0, revision 1.2 (Arar and Collins 1997). Fixed zooplankton samples were counted with an Olympus SZX-12 stereomicroscope and were identified using the keys of Pennak (1987) and Thorp and Covich (1991). Each zooplankton sample was counted in its entirety. 


\section{Calculations}

Pool-specific zooplankton population growth rates were calculated by using volume weighted-mean abundances of zooplankton. These values $(\mathrm{N})$ were entered into the population growth rate formula $r=(\ln (\mathrm{N}$ final $-\mathrm{N}$ initial))/time to obtain the specific growth rate of the population. Time refers to the transit times of the pools, which is the amount of time it took a parcel of water to travel from the upstream to the downstream sample site. Initial zooplankton densities $\left(\mathrm{N}_{0}\right)$ were considered to be the sum of the upstream and tributary inputs to the pools multiplied by the discharge of those sites; the downstream densities multiplied by discharge for each pool served as the final $\left(\mathrm{N}_{\mathrm{t}}\right)$ values. The sum of the upstream and tributary inputs were approximately equal to the downstream discharge $\left(y=0.72 x+281, R^{2}=0.48\right)$ where $x$ equals the sum of the upstream and tributary discharges and $y$ is equal to the downstream discharge. Data for this calculation were collected from USGS websites: McAlpine Pool http://nwis.waterdata.usgs.gov/ky/nwis/monthly/?site no=03294500\&agency $\mathrm{cd}=$ USGS, Kentucky River

http://nwis.waterdata.usgs.gov $/ \mathrm{ky} / \mathrm{nwis} / \mathrm{monthly} /$ ?site no $=03290500 \&$ agency $\mathrm{cd}=$ USGS., Smithland Pool

http://nwis. waterdata.usgs.gov $/ \mathrm{ky} / \mathrm{nwis} / \mathrm{monthly} /$ ?site no $=03399800 \&$ agency $\mathrm{cd}=$ USGS, and the Wabash River

http://nwis.waterdata.usgs.gov/in/nwis/monthly/?site no $=03377500$ \&agency $\mathrm{cd}=$ USGS. 
To determine the relationships between zooplankton population growth rates and environmental variables, growth rates were regressed in a step-wise multiple fashion with downstream discharge, mean pool chlorophyll $\alpha$, mean pool turbidity, and mean particulate organic carbon using the linear regression function in Systat Version 10 (Systat).

A three factor ANOVA was performed with Systat Version 10 to determine if differences existed between chlorophyll $\alpha$ between the 3 different rivers, 2 pools, or upstream and downstream reaches in each pool in 2002. The upstream reache refers to the upstream portion of a navigation pool and the downstream reach to the downstream portion. Discriminant functional analysis was used to compare densities of dominant zooplankton and to explore spatial and temporal similarities in zooplankton communities in 2002 between rivers, pools, and reaches. Data were grouped by date (June, July, August, and October), river (Ohio, Wabash, and Kentucky), pool (Smithland and McAlpine), and by pool/reach (upstream pool, mid-pool, and downstream pool in both the McAlpine and Smithland Pools). Data were also analyzed by groups and date. For example, discriminant functional analysis by groups/date was used to determine whether the dominant zooplankton taxa densities across rivers, pools, or reaches were similar on a given date.

\section{RESULTS}

Daily mean discharge at each of the three within pool sites for the McAlpine and Smithland and both tributary sites mirrored the catchment size of 
each river (Figure 2). Peak discharge occurred at all sites in June of 2001 and 2002 and was followed by decreased flow and peaks in late summer for both years. The Kentucky River displayed fairly uniform discharge on our sample dates. The range of water transit times in the McAlpine was from one to twelve days in 2001 and from four to thirteen days in 2002. The Smithland pool experienced a narrower range of transit times, from five to eight days during the study period.

Dominant zooplankton taxa at all sites included the rotifers: Asplanchna spp., Keratella cochlearis (Gosse 1851); cladocera: Daphnia lumholtzi (Sars 1885), Bosmina (sinobosmina) freyi and liederi (formerly Bosmina longirostris complex; O. F. Müller; DeMelo and Hebert, 1994) Diaphanasoma birgei (Fischer 1850); and copepods: cyclopoids (primarily Diacyclops and Mesocyclops), and calanoids (primarily Eurytemora affinis). Total mean zooplankton densities from all sampling sites ranged from 0 to 461.6 individuals per liter with a mean of 98.9 in 2001 and 2002. Keratella had the highest densities of all of the adult zooplankton with a mean of 16.9 individuals $\mathrm{L}^{-1}$ followed by Bosmina with 11.7, calanoids, 5.7, Daphnia 4.5, cyclopoids 3.0, Asplanchna 2.2, Diaphanasoma 1.5, and Branchionus 1.5 per liter. Nauplii and veligers had the highest densities with a mean of 23.0 and 16.7 individuals $\mathrm{L}^{-1}$ respectively. Total mean zooplankton densities (Figure 3) fluctuated throughout the study period. The Wabash typically had the lowest densities of zooplankton. When densities downstream were much higher than the combined densities of the tributaries and upstream densities, then within-pool population growth likely occurred. For example, dates 
with high densities at the downstream sites such as May, 2001 in the McAlpine Pool and in June and July, 2002 of the Smithland Pool corresponded with the positive population growth rates of individual taxa.

Daily zooplankton population growth rates were usually positive throughout 2001 and 2002. For example, Bosmina populations experienced positive growth for 12 of 16 surveys, Daphnia 7 of 10 surveys, Diaphansoma 5 of 10 , cyclopoids 8 of 13 , calanoids 6 of 16 , while Keratella growth rates were positive only 6 of 14 surveys (Figure 4). Stepwise multiple regression of the growth rates of individual taxa versus POC, turbidity, discharge, chlorophyll $\alpha$, and biotic interactions (larval and predator densities) with other taxa population growth rates indicated that zooplankton taxa may have varying responses to those parameters (Table 1). Increased discharge was negatively and significantly correlated with Daphnia $\left(p=0.049, R^{2}=0.397\right)$. Bosmina was negatively correlated with turbidity $\left(p=0.009, R^{2}=0.392\right)$ while Diaphanasoma rates were enhanced with the increase of $P O C\left(p=0.048, R^{2}=0.378\right)$. Cyclopoid growth was significantly correlated with three parameters $\left(R^{2}=0.726\right)$ : discharge $(p=0.012)$, turbidity $(p=0.002)$, and nauplii $(p=0.003)$. Both calanoid and Keratella growth rates were transformed due to the non-random scatter of the residuals. Calanoid rates were squared and were significantly and positively related to naupliar growth rates $\left(p=<0.0001, R^{2}=0.592\right)$, while the reciprocal of Keratella rates were inversely related to cyclopoid growth rates $\left(p=0.047, R^{2}=0.371\right)$.

According to the ordination analysis, there were no significant differences in zooplankton assemblages (Table 2 ) between dates (Wilks' lambda $p=0.23$ ), 
rivers (0.48), and pools, or rivers (0.35). However, there were significant differences among reaches $(<0.0001)$ across all 2002 sampling dates. There were also significant differences between rivers, pools and reaches on individual sampling dates (Table 3). For example, the zooplankton taxa composition differed significantly in the Kentucky, Ohio, and Wabash Rivers during July $(p=0.04)$ and October $(p=0.0026)$, but not in June or August, $(p=0.17,0.16)$ respectively. In July, the between groups F-matrix indicated that the Kentucky and Ohio Rivers were the least similar among rivers (5.57), followed by the Wabash and Kentucky (4.27). The Ohio and the Wabash had the most similar zooplankton communities (1.61). The zooplankton taxa that were most influential in determining community variability in July were Bosmina $(F$-to-remove $=9.26)$ and Branchionus (2.84) with the rotifers having greater densities in the Kentucky and Wabash Rivers and Bosmina being more numerous in the Ohio. Likewise, in October the Ohio and Wabash were the most similar (3.03) while the Ohio and Kentucky (151.63) and the Wabash and Kentucky (108.45) were dissimilar. Another cladoceran, Daphnia sp., was important in distinguishing clustering between communities (18.63) and was more common in the Ohio River.

There were statistically significant differences in zooplankton assemblages between the Smithland Pool and the McAlpine Pool in June (Wilk's lambda $p=0.0012)$, July $(p=0.0196)$, August $(p=0.0704)$ and October $(p=0.0003)$. In June, the zooplankton determining variability were Diaphanasoma (F-toremove $=40.43$ ) and Keratella (24.77), in July Diaphanasoma (6.05) and calanoids (6.70). In August, nauplii (14.66) and Bosmina (6.82) were influential 
while in October, variation was due to Keratella (33.87) and cyclopoids (33.89). In all months the zooplankton densities that caused variability were higher in the Smithland Pool except for calanoids in July, nauplii in August, and cyclopoids in October.

In 2002, there were significant differences between all reaches in June (Wilk's Lambda<0.0001), July (<0.0001), August $(<0.0001)$, and October $(<0.0001)$. In June, the cladocerans Daphnia $($ F-to-remove $=76.81)$ and Diaphanasoma (30.27) were the most influential in determining community variability as both experienced higher densities in the Smithland pool. Daphnia were also influential in July (17.24), when there were more Daphnia per liter at Vevay, the upstream site in the McAlpine Pool. Calanoids (54.48) and cyclopoids (39.19) were prominent in shaping community heterogeneity in August and both taxa showed higher densities at the downstream reaches of both the Smithland and McAlpine pools. Bosmina (323.76) and nauplii (84.36) accounted for most of the variation between sites in October, 2002. More Bosmina were found at the downstream reach of the Smithland pool while nauplii were abundant at the downstream reach of the McAlpine pool.

Within each pool, the similarity between the up and downstream sites varied on different dates. Lower F-matrix values indicate greater similarity compared to higher F-matrix values. For example the between groups F-matrix, showed that in the McAlpine pool the similarity between the upstream and downstream sites were $2.3,93.3,24.0$, and 157.8 for June, July, August, and 
October respectively. In the Smithland pool, the corresponding values for reach comparison were $9.0,1.3,146.5$, and 302.3 .

Between pools, the downstream reaches in each pool were often more dissimilar than other corresponding reaches between the pools. One exception is in July where the downstream reaches were much more similar to each other (3.41) than with their respective upstream reaches (77.51). The overall trend was that the upstream reaches were similar to each other, but the similarities diminished at the downstream reach, just above the dams.

Particulate organic carbon (POC) was typically higher in the McAlpine pool in 2001 than 2002 (Figure 5) and was higher in the tributaries than in the main stem Ohio River. Turbidity ranged from 4.5 nepholometric turbidity units (NTU) to 145 NTU, with the greatest values occurring in the tributaries. Turbidity was generally higher in the upstream reaches than the downstream reaches in both pools of the Ohio (Figure 6). These differences were more striking in the McAlpine than the Smithland Pool.

The tributaries also varied with each other and the Ohio in several respects. Chlorophyll $\alpha$ in the Kentucky and Wabash Rivers was generally higher than in the Ohio (Figure 7). Chlorophyll a concentrations in 2002 were different among rivers $(p=0.019)$ and pools $(p=0.0001)$; other factors such as survey date and reach were not significantly different $(p=0.053,0.080)$. Generally the tributaries had higher chlorophyll a concentrations than the main stem Ohio and the Smithland pool was higher in chlorophyll $\alpha$ concentrations than the McAlpine pool. 


\section{DISCUSSION}

These results indicate that the dominant zooplankton taxa (rotifers, and small cladocerans, such as Bosmina) in the Ohio River are similar to those in other studied rivers (Viroux 1997) and that discharge, POC, and turbidity are very likely important controlling factors of zooplankton population growth rates in the river. Zooplankton growth rates were usually greater than zero, indicating that the river can indeed be a source of zooplankton. The fact that reach was statistically significant on all dates for zooplankton community assemblages indicates that navigation dams do affect zooplankton community assemblages and agrees with the work of Pillard and Anderson (1993). These findings contrast with those of Thorp et al. (1994) in a previous study in the Ohio. In their study, Thorp et al. (1994) compared zooplankton densities above and below navigation dams and found no statistically significant differences. However, in their study there may not sufficient time or distance for community-level changes. They also used a different sampling regime than used here and their analysis included zooplankton densities only, not the population growth rates of these taxa.

Previous work with large river zooplankton communities has shown they have a different assemblage structure than that of lake communities (e.g. Guelda 2001, Saunders and Lewis 1988a; 1998b). For instance, rivers are often dominated by rotifers and small-bodied crustaceans such as Bosmina (Viroux 1997). This may be due in part to the different life history traits of the major zooplankton groups. For example, rotifers are capable of withstanding increased 
turbidity (Kirk and Gilbert 1990, Jack et al. 1993) and Bosmina is a selective feeder (Acharya et al. 2005) that may be able to feed more effectively under elevated turbidity than other cladocerans.

Seasonal succession of zooplankton communities in the Ohio River appears to be a function of multiple factors and discharge may be among the most important factors. Elevated discharges may lead to community dominance by rotifers and Bosmina, followed by larger crustaceans such as Daphnia and cyclopoids as the hydrographs dropped. Previous studies of riverine zooplankton have also concluded that discharge, velocity, and water residence times are paramount in regulating zooplankton densities (e.g. Pace et al. 1992, Thorp et al. 1994, Saunders and Lewis 1988). In a similar lock and pool system in the upper Mississippi River, Pillard and Anderson (1993) found that the lower, "more lacustrine" end of Pool 19 supported higher levels of zooplankton growth. Basu and Pick (1996) in a study of 31 rivers found that zooplankton biomass was positively associated with increasing water residence time. Other studies have also found that the growth of the riverine zooplankton population is often inversely proportional to discharge (Saunder and Lewis, 1988; Viroux 2002). Kobayashi (1997) found that copepod biomass was inversely related to river flow in the Hawksbury-Nepean, a regulated river in Australia. Baranyi et al. (2002) found a similar pattern in the Danube and argued that water stability is important in driving the succession of zooplankton from rotifers to larger crustaceans in that system. This relationship of zooplankton densities and reproduction with water transit time is consistent with the Inshore Retention Concept (IRC; Schiemer et 
al. 2001), which predicts that lotic systems with greater retention should support greater primary and secondary production.

The lack of a statistically significant association of Keratella, Bosmina and Daphnia with chlorophyll $\alpha$ levels in the river was somewhat surprising but is consistent with some other river studies (Van Dijk and Van Zanten 1995, Van Zanten and Van Dijk 1994; Pace et al. 1992, Guelda et al. 2005). However, Basu and Pick (1997) found that chlorophyll $\alpha$ was positively correlated with zooplankton densities. These findings, coupled with the strong effects of discharge, suggest that the significant effects of food quality and quantity (e.g. Guelda et al. 2005, Acharya et al. 2005) on river zooplankton population growth rates seen in experimental studies may not be easily "scaled up" to the river community in-situ. This has been a common critique of small-scale experiments, particularly mesocosms, in lake studies (Carpenter 1996). It should be noted, however, that discharges during the study period (2001-2002) were often higher than historical norms, particularly during the later summer and early fall. In addition, during the study period chlorophyll a levels never rose above $10 \mu \mathrm{g} \mathrm{L}^{-1}$ in the McAlpine Pool and were above $10 \mu \mathrm{g} \mathrm{L}^{-1}$ only once in the Smithland Pool. Guelda et al. (2005) found that that the incipient limiting thresholds for Bosmina and cyclopoids were $0.018 \mathrm{mg} \mathrm{C} \mathrm{L}^{-1}$ and $0.011 \mathrm{mg} \mathrm{C} \mathrm{L}^{-1}$ respectively, (using a ratio of 20:1 of chlorophyll:algal carbon). Therefore, the zooplankton growth rates may have been constrained by resource levels during the period of my study. Discharge may affect chlorophyll $\alpha$ concentrations by increasing turbidity 
and decreasing light penetration, but neither discharge nor turbidity were significantly associated with chlorophyll $\alpha$ in this study (see Results).

The zooplankton community assemblages were similar (except at the reach level) across all dates despite the differing rivers and pools where they were collected. This does not agree with the results of Guelda (2001), who in a multi-year study found significant differences among upstream and downstream sites in the Ohio River and several of its tributaries across all dates. She did not specifically test sites within navigation pools, but she found greater heterogeneity in zooplankton communities in the downstream sites in her study, while the upper and mid river sites displayed less variability. Our sites corresponded with her upper and mid river sites and in these reaches our results are consistent with hers (i.e., we also found no variation across all dates in these sites.) The tributary sites with the most variability in her study, the Cumberland and Tennessee Rivers, drain reservoirs and had a high concentration of Bosmina, cyclopoids, and rotifers but these tributaries were not included in this study. The differences between my study and Guelda's may have also been driven by the unusual discharge regime during the study period.

In Guelda's tributary analysis, the Kentucky and Wabash were similar to each other but not similar to other tributaries (Green, Cumberland and the Tennessee) that drain reservoirs. I did not include the latter three rivers in my study, but I found the opposite trend, with Wabash and the Ohio often being more similar to each other than either were to the Kentucky in July and October. I think my patterns are best explained by the relative discharges of the tributaries. 
During my study period, the Wabash was responsible for a significant percentage, (approximately 40\%) of total flow at the point it entered the main stem Ohio River. The Kentucky River had significantly higher chlorophyll a than the main stem of the Ohio River, which I expected might influence zooplankton population growth rates below the confluence (Basu and Pick 1996). However, the Kentucky's discharge is relatively small at its Ohio River confluence it (typically less that $10 \%$ of total discharge). Therefore tributary inputs had no influential effect on zooplankton population growth in the main stem. The role of cladocerans in distinguishing the main stem Ohio River communities from that in the tributaries is important and should be studied further.

Within each pool, the similarity between the up and downstream sites varied on different dates and may be explained by discharge. During the beginning of each season, discharge was higher and the upstream and downstream reaches were more similar than at the end of the season when discharge was low. Pillard and Anderson (1993) in their study of the Upper Mississippi found that zooplankton densities differed between reaches at low flow, but were more similar during high flow. Perhaps during low flow periods, biotic interactions have greater opportunity to express themselves and lead to different communities in the downstream reach. In contrast, high discharge in a pool may make prevailing conditions more uniform and prevent biotic interactions from becoming dominant controls on zooplankton densities even at the more lacustrine, downstream reach. 
Within each pool, chlorophyll $\alpha$ was not significantly different between reaches on each date, but the zooplankton assemblages were. This indicates that food availability may not be limiting, but acquisition could be difficult due to competition with other zooplankton or characteristics of the upstream site such as increased velocity. Abilities such as feeding in a turbid environment, swimming ability, and the differing reproductive modes utilized by the various zooplankton taxa may explain their success in different reaches of the pools. I expected that rotifers would thrive in the upstream portions of the pools, because they can feed constantly in turbid environments and are usually parthenogenetic. I also expected that copepods might perform well in upstream portions because they are good swimmers (Richardson 1992) where velocity is typically higher. Cladocera are poor swimmers (Richardson 1992) and are negatively affected by turbidity (Kirk and Gilbert 1990), so I assumed they would dominate the lower turbidity, more lacustrine downstream reaches. However, in the Smithland pool Keratella densities increased downstream and Daphnia were more abundant in the upper reach of the McAlpine Pool, which was opposite of my expectations. Cyclopoids and Daphnia distributions were consistent with my expectations in the Smithland pool. The higher than expected Daphnia densities in the upstream portion of the McAlpine may have been the result of the inputs from the Markland Pool just above it, but I have no data from the Markland to confirm that.

River reaches with upstream dams tend to act as a lake-river system (e.g. Pourriot et al. 1997, Jackson et al. 1981), while reaches with downstream dams are the opposite, a river-lake system (e.g. Pillard and Anderson 1993, Kim and 
Joo 2000). These differing characteristics can provide insight as to whether zooplankton communities are controlled by habitat characteristics or river continuity (e.g. Vannote et al.1980). Navigation pools in the Ohio River behave as a river-lake system, but in a series. Each of the aforementioned studies determined that larger bodied crustaceans persist only in reservoir-like areas while rotifers dominate in constricted, riverine portions. There is substantial evidence that zooplankton communities in these habitats are different despite their sequence, which suggests that habitat, rather than river continuum characteristics, are responsible for different zooplankton communities in regulated rivers. The Ohio River is similar to other rivers with upstream dams and my findings support the fact that habitat is an extremely important factor in controlling communities and species dynamics, such as succession. There is a possibility that during periods of high discharge or frequent spates, zooplankton communities are more similar and dominated by rotifers and small cladocera. At low discharge or spate frequency, heterogeneity in the zooplankton communities may be determined by the individual river or pool characteristics. These communities would be less likely to be dominated by rotifers and more by copepods and large cladocera.

It seems fairly obvious that water residence time, a result of discharge rate, plays a significant role in affecting densities of riverine zooplankton. However, the mechanisms by which hydrology controls zooplankton assemblages needs to be investigated experimentally. Possible mechanisms that have been tested include the negative impacts of turbidity (Jack et al. 1992), 
decreased light penetration and thus algal resources (Sellers 2001) or decreased foraging efficiency in a turbulent environment.

It may be argued that navigation dams increase autochthonous production in large rivers and without dams, fewer zooplankton would be present. However, unregulated rivers may have greater habitat heterogeneity due to less uniform flow (Poff et al. 1997), larger variation in hydrographs and by habitats such as backwater areas (Spaink et al. 1998), floodplains (Keckeis et al. 2003), and macrophyte beds that would serve as a source of zooplankton (Basu et al. 2000). However, the lack of "reference" rivers makes such a comparative study difficult. Yet, if dam removal and restoration activities in the rivers of the US continue, these important habitats may be numerous enough to support and perhaps even enhance existing riverine food webs. 
CHAPTER III

THE IMPACT OF WATER COLUMN VELOCITY ON THE GRAZING AND COMMUNITY DYNAMICS OF OHIO RIVER ZOOPLANKTON: A MESOCOSM EXPERIMENT

\section{INTRODUCTION}

The effects of water movement, either in one plane (such as velocity) or multiple planes (turbulence) on zooplankton are well-studied in marine systems. In the marine environment, turbulence can affect zooplankton from the individual to the ecosystem level (Alcaraz 1994). For example, increased turbulence increased the heartbeat rates of Calanus gracilis (Alcaraz et al.1994), as well as ammonia and phosphate excretion (Saiz and Alcaraz 1994). Increased turbulence instigated an escape response in marine calanoid copepod, Centropages hamatus (Costello et al. 1990) and was associated with reduced zooplankton egg production (Saiz et al. 1992). Turbulence affected marine 
zooplankton herbivory by decreasing clearance rates (Saiz et al. 1992, Saiz 1994) and by interfering with particle reception (Bundy and Vanderploeg 2002).

There have been fewer studies assessing hydrological effects such as velocity or turbulence on freshwater species. Higher turbulence was linked to higher growth rates in Daphnia retrocurva (Brooks 1947) and increased heart rates in Daphnia pulex (Alcaraz et al.1994). Zooplankton distributions in the Meuse River were found to be more homogeneous and less abundant during high flow periods (Marneffe et al. 1996). Richardson (1992) used a velocity chamber to measure wash-out times of zooplankton and discovered that stream Daphnia were less able to withstand higher velocity treatments than copepods.

In a behavioral investigation of the effects of velocity on zooplankton swimming, Seuront et al. (2004) determined that freshwater Daphnia pulicaria escape responses increased with increasing turbulence intensity, while those of the marine copepod Temora did not. Their conclusion was that Temora had adapted to turbulent conditions present in marine systems over time, while Daphnia was apparently still coping with velocity as a force of selection. The investigators related this to the habitat source of the studied animals; Temora reside in shallow tidal zones that are dominated by in- and out-going waves while Daphnia are commonly found in the comparatively low-velocity water column of lakes.

In contrast to the long history of hydrological studies in marine systems, comparatively few studies have addressed the potential effects of hydrology in highly turbid freshwater systems such as large rivers. There are several key 
observational studies that identify the advective effects of water as drivers of zooplankton densities and community dynamics in freshwater systems. In a comparative study of the Hudson River, USA with other large rivers, estuaries, and lakes, Pace et al. (1992) outlined the positive relationship between zooplankton biomass and increased water residence times and noted that smaller zooplankton are more typical dominants in large rivers while large zooplankton dominate lakes. In other studies of lotic systems, a more diverse and dense zooplankton community was present in the pools rather than riffles of the Illinois River, Arkansas, USA (Brown et al. 1989), in lake-like navigation pools of the Upper Mississippi River (Pillard and Anderson 1993), and in a backwater area of the River Waal, The Netherlands (Spaink et al. 1998) than in the main channel habitats. These spatial observations along with temporal relationships with water residence times across sampling seasons (e.g. Reckendorfer et al. 1999; Baranyi et al. 2002) led to the development of the Inshore Retention Concept (IRC) by Shiemer et al. (2001). This concept asserts that biotic interactions such as herbivory, predation, and competition are greater in areas or during periods of low flow. However, during or in areas of high flow, biotic interactions are overwhelmed by the physical effects of increased flow so diversity and densities of zooplankton during these periods or areas should be decreased. These physical effects could include the effects of turbidity, turbulence or velocity, or possible light and resource limitation.

While these observational studies have made important contributions to our understanding of how zooplankton respond to flow variation in large rivers, 
no one to my knowledge has approached this problem experimentally by manipulating the velocities experienced by riverine zooplankton communities and assessing their responses. In part this is due to the difficulties in conducting experiments with large and essentially unreplicatable systems such as rivers. However, researchers have been able to work with zooplankton communities in the Ohio River USA using both in-situ (e.g. potamocorrals, Jack and Thorp 2000) and shore-based (Guelda et al. 2005) mesocosms. Large mesocoms allow researchers to manipulate important ecological parameters such as density (Guelda 2001), while still providing a realistic environment for zooplankton that reduces the potential for "container effects." Such an approach allows the investigation of a number of unanswered questions about the effects of changes in flow velocity in rivers such as the Ohio on zooplankton. For example, increased velocities are often associated with increased turbidities, which could negatively affect phytoplankton production, and thus algal resources available to zooplankton, in these light-limited systems (Sellers and Bukaveckas 2003). However, elevated flow may also direct large amounts of POC from the watershed into the river or keep POC already present in suspension longer so it could be accessed by the zooplankton. High flow may also prevent capture of food particles due to the cost of locomotion. On the community level, rotifers tend to dominate in the Ohio River during high flow periods in the winter and early spring, but it is unclear whether this is due to their tolerance of high turbidities (Jack et al 1993), ability to feed continuously in a turbid environment 
(Kirk and Gilbert 1990), differences in food selectivity, threshold food levels (see Chapter One), or some combination of these factors.

Using large mesocosms and zooplankton communities from the Ohio River (USA), allows me the opportunity to uncouple these factors and test them singly. I tested the hypotheses that current velocity has a direct negative effect on zooplankton growth rates and community composition, as indicated by dominance shifts, in the Ohio River. Specifically, I assessed the response of zooplankton communities to water velocities characteristic of high (April) and low (August) flow conditions in the river in terms of the population growth rates of the numerically dominant taxa and the species composition of the zooplankton over 14 day incubations in the spring and the fall. This approach allowed me to assess the effect of water velocity independently of other potentially confounding factors such as temperature and phytoplankton community structure which often co-vary with flow velocity across seasons.

Because April typically experiences high flow conditions, I expected rotifers would initially dominate all of the tanks in the April experiments but that cladoceran population growth rates would increase in the low velocity treatments where physical conditions would not increase the metabolic costs and hinder grazing. Copepods are typically strong swimmers. Thus, I expected that they might experience positive population growth in the high velocity tanks. In August, I expected less initial dominance by rotifers and that high velocity tanks would suppress cladoceran population growth rates and boost rotifer and copepod growth rates. In the low velocity tanks I expected the opposite impacts on 
population growth rates. I expected that chlorophyll a would differ between the April and August experiments due to the difference in phytoplankton communities during those seasons. I expected that low velocity tanks with high zooplankton densities would negatively impact standing crop chlorophyll a concentrations more than grazers in high velocity tanks due to higher metabolic and locomotion costs to zooplankton under those conditions.

\section{METHODS}

The Ohio River is a large, regulated river and is the second largest river in the United States by discharge (Thorp et al. 1994) and length (Guelda 2001). The river is divided into navigation pools by low-head navigation dams that maintain a minimum water depth for barge traffic. These navigation pools are characterized by a shallow water column just below navigation dams and a deeper portion just upstream of each dam. The depth of the water column and velocity in different parts of the pool impacts light penetration, turbidity and thus phytoplankton growth (Sellers 2001).

I performed mesocosm experiments in April and August 2004 at the Ohio River Experimental Station (ORES) in Westport, Kentucky. Westport is at the mid-pool site of the McAlpine Pool of the Ohio River (ORK 933) upstream of Louisville, Kentucky.

In order to understand the potential ecological significance of velocity on zooplankton foraging, population growth rates, and community dynamics, it was necessary to establish similar conditions between the tank manipulations and 
actual conditions in the Ohio River. Because I could not measure turbulence in the river and velocity varies with wind, depth and proximity to shore, I used water transit times and dimensional analysis to calculate velocities for the tank that would be representative of river velocities. Transit time is the time that it takes a parcel of water to travel from the upstream site of the pool to the downstream site and is usually measured in hours or days. Higher velocities equate to low water residence times and vice versa. Transit times typically range between 1-30 days in the McAlpine Pool (Thorp et al. 1994, Guelda 2001). Using this range and the length of the McAlpine Pool $(119 \mathrm{~km})$, I converted this distance to meters and divided by transit time in seconds to arrive at velocities in $\mathrm{m} \mathrm{s}^{-1}$ range that were representative of the McAlpine Pool.

A circular, uni-directional channel $80 \mathrm{~cm}$ deep was created by placing a 55 gallon drum in the center of each tank (Figure 8). To manipulate velocity, I used pumps with varying capacities to achieve the velocities associated with high and low transit times in the McAlpine Pool (see chapter 2 for a description of the Ohio River navigation pools). In the low flow treatments, I used only one low capacity pump $\left(600 \mathrm{Ih}^{-1}\right)$ which created a velocity of $0.064 \mathrm{~m} \mathrm{~s}^{-1}$, equivalent to a twenty day transit time. In the high flow treatments, I placed six high capacity pumps ( each $1200 \mathrm{Ih}^{-1}$ ) in the tank; three pumps were placed on the drum and three were placed on the tank wall. The velocity generated in the high tanks was $0.32 \mathrm{~m} \mathrm{~s}^{-1}$, corresponding to the water velocity of a four day transit time. To find the "dead spots" or areas of low velocity in the tanks, I used 1200 plastic $6 \times 9$ $\mathrm{mm}$ plastic pony beads and observed where they settled. There was some 
settlement of the beads near the base of the barrels, but most of the beads continued to circulate even in the low velocity areas.

At the onset of each experiment, I pumped Ohio River water into a tank for fifteen minutes, and then rotated to another tank in order to decrease the variation in initial water conditions among the tanks. All water was filtered through a $63 \mu \mathrm{m}$ mesh to remove larger zooplankton (=macrozooplankton) grazers. Six tanks ( 3 high velocity and 3 low velocity tanks) remained free of macrozooplankton; the other six tanks ( 3 high velocity and 3 low velocity tanks) were each inoculated with enough macrozooplankton from the river to bring the final concentrations to ambient river densities.

Samples were collected on the following days: $0,3,6,9,11$, and 14 . I collected zooplankton samples, whole chlorophyll, turbidity, particulate and dissolved organic carbon (POC and DOC), dissolved and particulate nutrients. I used a Hydrolab to collect information on temperature, specific conductance, $\mathrm{pH}$, dissolved oxygen, and percent saturated dissolved oxygen. Zooplankton samples were collected from all tanks by pumping water through a $20 \mu \mathrm{m}$ net using a manual diaphragm pump. Triplicate samples of ten liters were taken from each tank and fixed with $10 \%$ sugared formalin (Haney and Hall 1974). Zooplankton were identified to various taxon levels and counted on a Nikon dissecting microscope and were identified using the keys of Pennak (1987) and Thorp and Covich (1991). Daily population growth rates were calculated for dominant zooplankton taxa from day 0 to day 14 in April and August in the high and low velocity tanks using the following formula: $r=(\ln (N$ final $-N$ 
initial))/time. The daily population growth rate ( $r$ ) was equal to the natural log of the difference between zooplankton densities on day $14(\mathrm{~N}$ final) and day $0(\mathrm{~N}$ initial) divided by the experiment length (14 days).

Turbidity was determined in the laboratory using a Hach $2100 \mathrm{P}$ Turbidometer. POC was collected from grab samples and determined by the ash free dry mass method. Chlorophyll $\alpha$ was also taken from grab samples and cold-extracted using $10 \%$ buffered acetone for 24 hours. The extract was then analyzed fluorometrically on a Turner Designs fluorometer based on U.S. EPA standard methods 445.0, revision 1.2 (Arar and Collins 1997).

\section{Data Analysis}

Zooplankton population growth rates were analyzed for statistical significance on each date with a single factor ANOVA using Systat 10.2. Since collection date was analyzed separately, velocity was the only factor considered in the model. POC and whole chlorophyll a were analyzed using a general linear model with both categorical and continuous explanatory variables. The categorical variables (month, day, velocity, and tank) were entered into the model with month, day, and velocity considered fixed-effect variables. All variables were crossed with each other and all possible interactions of them were included in the model. Tank was considered a random effects variable and was nested in both velocity and month. Continuous explanatory variables (turbidity and grazer density) were entered into the model along with their first order interactions with month and velocity. The interactions of the continuous variables were dropped 
from the model only if there were non-significant by tests of hypotheses using type III analysis. Terms were dropped from the model in a stepwise manner based on p-values. All tests of hypotheses were based on type III analysis and used F-ratios generated by the random sub-command of proc GLM in SAS. In the analysis of whole chlorophyll $\alpha$, a single data point with a standardized residual of -6 was considered an outlier and removed from the data.

\section{RESULTS}

Zooplankton densities in April were as much as two orders of magnitude lower overall than in August (Figure 9). In the April experiment, mean rotifer densities ranged from 0.1 and 1.2 individuals $L^{-1}$ and in August rotifer densities ranged from 0.62 to 313.67 individuals $\mathrm{L}^{-1}$. Mean cladoceran densities (primarily Bosmina) were fairly low in both experiments, particularly in April (0 to 0.32 individuals $L^{-1}, 0.45$ to 7.67 individuals $L^{-1}$ in August.) Mean copepod densities ranged from 0 to 0.4 individuals $L^{-1}$ in April and 0.2 and 24.4 individuals $L^{-1}$ in August.

Mean population growth rates calculated over a 14-day period of all dominant zooplankton were higher in August than April. They were also higher in low velocity tanks than high velocity tanks in both months (Figure 10). Under low velocity, mean rates averaged 0.20 per day in August and 0.02 per day in April. Rates in high velocity tanks averaged 0.14 per day in August and -0.08 per day in April throughout the experiment. During the April experiment, only the rotifer, Keratella and nauplii exhibited positive population growth in high and low velocity tanks respectively. Positive population growth of nauplii likely represents 
increased reproductive success of adult copepods while negative $r$ values for nauplii may indicate metamorphosis to copepodite stages rather than mortality. The Bosmina population maintained the same size in the low velocity tanks, but dropped in the high velocity tanks. In August, Keratella, Branchionus, Bosmina, and calanoids experienced positive population growth under both velocity regimes, while cyclopoids exhibited negative growth in both treatments. Nauplii exhibited positive growth in low, but not high velocity tanks for the span of the experiment. Table 4 summarizes the single factor ANOVA results, which tested months separately, but looked for significant differences in population growth rates of taxa between high and low velocity tanks throughout the fourteen day experiment. Only nauplii and Keratella growth rates were analyzed in April, due to either missing samples or zero population sizes of other taxa. Keratella growth rates were not significantly different at different velocities in April $(p=0.18)$, but were in August, with higher growth in the high velocity tanks (0.038). Nauplii rates significantly differed in both months with positive growth in low velocity tanks and negative population growth in high velocity tanks (April and August $p=0.001$ ). Bosmina growth rates differed between velocity treatments in August $(p=0.024)$ with higher rates in low velocity tanks. Branchionus $(p=0.77)$, calanoid $(p=0.12)$, and cyclopoid $(0.67)$ growth rates were not significantly different due to velocity throughout the span of the August experiment.

In April, POC values throughout the experiment ranged from 0.9 to 19.89 $\mathrm{mg} \mathrm{L}^{-1}$, and values declined following the initiation of the experiment except for a spike in the high treatments on day 11 (Figure 11a). High velocity tanks 
generally had higher POC concentrations. In August, the initial POC concentrations at the start of the experiment were lower than April, but showed nearly the same trend over time (Figure 11b). None of the zooplankton groups were found to affect POC significantly during the April and August experiments (cladocerans $p=0.32$, copepods $p=0.97$, rotifers $p=0.94$, nauplii $p=0.41$ ). Velocity had a highly significant effect $(p=0.0048)$ on POC (Table 5$)$. The only other significant factor affecting POC was day, which was highly significant and negative $(p<0.0001)$ and likely indicates settling of particles. In April, turbidity in the tanks began at 173 NTUs and dropped to 36.8 and 20.5 NTUs in the high and low velocity tanks, respectively. Turbidity ranged from an initial level of 62.7 NTUs down to 2.8 NTUs in the high and 2.2 NTUs in the low velocity tanks in August.

In April, the initial whole chlorophyll $\alpha$ concentration was much lower than the initial conditions for the August experiment (Figures $12 \mathrm{a}, \mathrm{b}$ ). The range of whole chlorophyll $\alpha$ in the April experiment was 0.08 to $0.37 \mu \mathrm{g} \mathrm{L}^{-1}$ and 0.07 to $0.37 \mu \mathrm{g} \mathrm{L}^{-1}$ in the high and low tanks, respectively, while the ranges in August were 2.2 to $51.8 \mu \mathrm{g} \mathrm{L}^{-1}$ in the high tanks and 0.3 to $36.2 \mu \mathrm{g} \mathrm{L}^{-1}$ in the low velocity tanks. Whole chlorophyll a (Figure 12a) in April decreased from the initial concentrations, while chlorophyll $\alpha$ in August (Figure 12b) increased until day 6 of the experiment and thereafter declined. Comparatively, in the 2001 and 2002 survey, chlorophyll $\alpha$ ranged from 0.12 to $27.8 \mu \mathrm{g} \mathrm{L}^{-1}$ in the McAlpine Pool and as high as $50.2 \mu \mathrm{g} \mathrm{L}^{-1}$ in the Smithland Pool in 2002. Using the chlorophyll:carbon ratio reported in Guelda at al (2005), whole algal carbon in April ranged from 
0.003 to $0.019 \mu \mathrm{g} \mathrm{CL}^{-1}$ in the low tanks and from 0.004 to $0.019 \mu \mathrm{g} \mathrm{L} \mathrm{L}^{-1}$ in the high tanks. Algal carbon was as high as $2.59 \mu \mathrm{C} \mathrm{L}^{-1}$ in the high velocity tanks and as low as $0.015 \mu \mathrm{g} \mathrm{C} \mathrm{L}^{-1}$ in the low velocity tanks in August.

Analyses using the general linear model (Table 6) demonstrated that the interaction of rotifers and velocity on whole chlorophyll a were significant $(p=0.0134)$. Contrast analysis showed that rotifers had a negative effect on chlorophyll $\alpha$ in both high and low velocity, but the effect was greater in low velocity tanks than the high velocity tanks (slopes of -0.001082 and $0.00008752)$. No other taxonomic groups significantly affected whole chlorophyll concentrations (cladocera $p=0.62$, copepods $p=0.91$ ). The interactions of month was significant $(p<0.0001)$ while velocity $(p=0.48)$ and turbidity $(p=0.13)$ were not. The interaction of month and rotifers was not significant and was dropped from the analysis.

\section{DISCUSSION}

These experiments are the first to experimentally study the effects of velocity on riverine zooplankton population growth rates and community dynamics and the first to do so in large volume mesocosms designed to mimic river conditions in situ. Most other studies have been carried out with laboratory monocultures in small volume containers and have focused largely on marine zooplankton and rarely on Daphnia from lakes (see above). While there are well acknowledged limitations to mesocosm experiments (Carpenter 1996), these experiments correlated extremely well with the results of field studies in that 
rotifer population growth rates are comparatively higher during higher flows and larger crustaceans higher during decreased flow. These findings demonstrate that velocity is an important direct physical mechanism which can impact zooplankton densities. The effects of velocity on zooplankton populations likely have emergent effects on community and ecosystem parameters such as succession and biomass, respectively. Furthermore, differential taxon responses to velocity may be adaptations to particular aquatic environments in large rivers or across aquatic systems.

Velocity affected resource and physical parameters in mesocosms in both expected and unexpected ways. The direct effects on suspended POC were expected, as the particulate matter would be less likely to settle under higher rather than lower velocity conditions. I did expect that grazers might affect POC values because it is a potential food source, but this carbon fraction appeared to be completely under the physical control of velocity in these experiments.

This is the first study to show experimentally that rotifers can have a significant impact on chlorophyll a levels in river plankton. The effects of rotifers were statistically significant regardless of the seasonal or months effect on phytoplankton communities. Therefore, rotifers appear to be efficient and important riverine grazers throughout the typical sampling season. Rotifers are the most common zooplankton numerically in large rivers and during periods of high discharge in these systems (e.g. Thorp et al 1994). Because the cost of locomotion is high for rotifers (Epp and Lewis 1984), higher velocity could decrease metabolic costs and therefore increase reproductive success. They 
have also been shown to be tolerant of suspended mineral turbidity (Kirk and Gilbert 1990) and turbidity is usually elevated during periods of high velocity. Since rotifer growth seems to be favored under the conditions of high velocity, it is likely that the higher particle encounter rate present in more turbulent environments would have enhanced rotifer feeding. The population growth rates of Keratella was always greater in the high velocity treatments in each of the study months. This correlates well with other studies that have shown rotifer dominance in rivers, particularly during higher flow (Saunders and Lewis 1988, Viroux 1997).

Given higher rotifer growth rates in the high velocity tanks, I was surprised that the rotifer's proportionate impact on chlorophyll $\alpha$ was stronger in the low velocity tanks in April rather than the high velocity tanks. This suggests that the higher velocity treatment may have had other negative but unquantified effects on rotifer population responses that could outweigh any benefits of increased particle encounter rates or reduction in sinking rates. For example, many rotifer females carry their eggs externally and these may be subject to detachment and loss as velocity increases.

Earlier field studies (e.g., Jack et al. 1993) of the differential effects of turbidity on zooplankton were done in low-velocity lake environments. Mineral turbidity in a turbulent environment may have more unpredictable effects including physical damage to zooplankton including rotifers. It is interesting that the rotifers in the Ohio River are commonly dominated by "armored" forms such as Keratella (e.g. Williams 1966, Thorp et al 1994) whose stiffened outer 
integument may provide some protection against abrasion by suspended mineral particles. I know of no data assessing the relationship between turbidity or velocity and ingestion rates by rotifers. In their work with larval fish, Mackenzie et al. (1994) found ingestion rates displayed a hump-shaped relationship with velocity. Rotifers may show a similar response. More work with a broader range of velocity values is needed to quantify the impact of velocity on clearance and ingestion rates by rotifers and other zooplankton.

I had hoped to be able to evaluate the response of cladocerans, particularly daphniids, during these experiments. However, densities of these animals remained relatively low probably due to the high river flow rates even in August. Daphnia densities in large rivers are typically quite low compared to lakes (Pace et al. 1992). Densities drop dramatically in the transition from lake to riverine habitats (Threlkeld 1986), and negative impacts due to turbulence have been investigated (Alcaraz et al. 1994). Further velocity experiments capturing the dynamics of Daphnia would be extremely interesting.

I expected that copepod growth would be greater in high velocity conditions relative to low velocity treatments, because of enhanced particle encounter rates, and their strong swimming ability (Richardson et al. 1992) and adaptations to turbulent conditions in marine systems (Seuront et al. 2004). However, an experiment by Alcaraz et al. 1988 using small marine microcosms $\left(30 \mathrm{dm}^{3}\right)$ showed that increased turbulence decreased the number of male copepods and increased metabolic activity and excretion rates. The comparatively higher densities of copepods in the low velocity tanks could have 
resulted from potential feeding interference or recruitment in the high velocity tanks. Calanoid and cyclopoid growth rates demonstrated opposing trends as cyclopoid rates were negative across all treatments and dates, while calanoid populations experienced positive growth during the August experiments. The fact that there were more nauplii as well as adult copepods at the end of the experiment in the low velocity tanks indicates that velocity may affect copepod mating and offspring survivorship. Observations of copepods mating have shown that a male may swim adjacent to a female for 20 seconds before mating (Strickler 1998). This may prove difficult in high velocity conditions.

In August, despite the low starting densities of cladocera and copepods, the communities shifted toward a larger bodied, crustacean-dominated assemblage in the low velocity tanks, supporting my hypothesis that decreased velocity favors these more "lacustrine" groups. The fact that a community shift did not occur in the high velocity tanks suggests that the higher water velocity prevented "succession" from rotifer- to crustacean-dominated communities. Cladocera, especially Daphnia, often out-compete rotifers via exploitative and interference competition in laboratory (Gilbert 1985b) and field experiments (Gilbert 1988b) and copepods can directly suppress rotifers via predation (Plamann et al. 1997, Lapesa et al. 2001, Ramos-Rodriguez et al. 2004). Such biotic interactions may be more important under low velocity conditions. Bosmina populations were present in higher densities than those of Daphnia and grew faster in low velocity tanks (and later in the season). This may indicate the 
importance of time and/or low flow conditions for community succession away rotifers to larger crustaceans in large rivers.

I expected there to be a significant impact of the crustacean community on whole chlorophyll $\alpha$ concentrations in low velocity tanks in August, but that was not the case. One possible explanation might be predation of the large zooplankton on protists or rotifers rather than algal food resources. In a mesocosm study testing zooplankton resource limitation, Guelda et al. (2005) suggested that copepods shifted to eating autochthonous non-algal sources. The importance of rotifers as grazers of phytoplankton has interesting implications for riverine food webs. In large rivers, rotifers are often more common (Shiel et al. 1982). The stronger influence of rotifers rather than cladocera or copepod grazing on phytoplankton has been noted by Gosselain et al. (1998) with in situ grazing chambers in the Meuse and Moselle Rivers and by Kobayashi et al. (1996) in the North Richmond River, Australia.

My results were consistent with most of the observational studies of zooplankton in rivers across the world. Rotifers performed well during high flows and communities shifted towards cladocera and copepods in lower velocity conditions. Thorp et al. (1994) found higher densities of zooplankton near the shore, which may be due to decreased velocity associated with those habitats. Turbidity was tentatively ruled out as a major factor influencing river zooplankton impacts on whole chlorophyll $\alpha$ and community assemblages. It also appears as if chlorophyll resource quantity was not limiting during these experiments, although quality cannot be ruled out. These results also correlate with previous 
turbulence experiments as velocity acted negatively on Daphnia (Alcaraz et al. 1994) and may interfere with copepod foraging (Costello et al. 1990) or reproduction.

River regulation alters velocity and habitats (Sluss in prep) by creating retention areas behind dams. However, unregulated rivers often have more contact with their flood plain, and more macrophytes (Poff et al. 1997).

Managers should consider the presence of low velocity habitat in the restoration of large rivers in order to support biotic interactions and provide a resource base for commercially important fish larvae. Also, my results indicate that velocity is an important factor and should be integrated into other experimental mesocosm studies of lotic systems to insure ecological similarity between actual and simulated habitats. 


\section{TABLE 1}

Multiple regression results for population growth rates of zooplankton taxa vs. environmental factors particulate organic carbon (POC), discharge, chlorophyll $\alpha$, and turbidity.

\begin{tabular}{|c|c|c|c|c|}
\hline Zooplankton & $\begin{array}{l}\text { Corrected } \\
\text { R-Squared }\end{array}$ & $\begin{array}{c}\text { Significant } \\
\text { Factors }\end{array}$ & $p$-value & Coefficient \\
\hline Bosmina & 0.392 & Turbidity & 0.009 & -0.022 \\
\hline Daphnia & 0.397 & Discharge & 0.049 & -0.001 \\
\hline Diaphanasoma & 0.378 & POC & 0.048 & 0.222 \\
\hline Calanoid & 0.592 & $\begin{array}{l}\text { Nauplii } \\
\text { Growth } \\
\text { Rates }\end{array}$ & $<0.0001$ & 0.183 \\
\hline Cyclopoid & 0.726 & $\begin{array}{c}\text { Discharge } \\
\text { Turbidity } \\
\text { Nauplii } \\
\text { Growth } \\
\text { Rates }\end{array}$ & $\begin{array}{l}0.012 \\
0.002\end{array}$ & $\begin{array}{c}-0.001 \\
0.031\end{array}$ \\
\hline Keratella & 0.371 & Cyclopoids & 0.047 & -0.609 \\
\hline
\end{tabular}




\section{TABLE 2}

Results for discriminant functional analysis based on groups date, river, pool, and reach in 2002. Values in bold represent statistical significance.

\begin{tabular}{|c|c|}
\hline Group & $\begin{array}{c}\text { Wilk's Lambda } \\
\text { p-value }\end{array}$ \\
\hline Date & 0.2282 \\
(June, July, August, October) & 0.4777 \\
\hline $\begin{array}{c}\text { River } \\
\text { (Wabash, Kentucky, Ohio) }\end{array}$ \\
\hline $\begin{array}{c}\text { Pool } \\
\text { (Smithland, McAlpine) }\end{array}$ \\
\hline $\begin{array}{c}\text { Reach } \\
\text { (Up, Mid, Down in each Pools) }\end{array}$ \\
\hline
\end{tabular}




\section{TABLE 3}

Results for discriminant functional analysis comparing rivers, pools, and reaches on different sampling dates in 2002 . Values in bold represent statistical significance.

\begin{tabular}{|c|c|c|c|c|}
\hline Sampling Sites & June & July & August & October \\
\hline $\begin{array}{c}\text { River } \\
\text { (Wabash, Kentucky, } \\
\text { Ohio) }\end{array}$ & 0.1649 & $\mathbf{0 . 0 4 2 2}$ & 0.1556 & $\mathbf{0 . 0 0 2 6}$ \\
\hline $\begin{array}{c}\text { Pool } \\
\text { (Smithland, McAlpine) }\end{array}$ & $\mathbf{0 . 0 0 1 2}$ & $\mathbf{0 . 0 1 9 6}$ & 0.0704 & $\mathbf{0 . 0 0 0 3}$ \\
\hline $\begin{array}{c}\text { Reach } \\
\text { (Up, Mid, Down in each } \\
\text { pools) }\end{array}$ & $<0.0001$ & $<0.0001$ & $<0.0001$ & $<0.0001$ \\
\hline
\end{tabular}




\section{TABLE 4}

Single factor ANOVA results testing for differences in population growth rates between high and low velocity tanks. Probability values in bold represent significant difference between turbulence treatments. Months were analyzed separately.

\begin{tabular}{|c|c|c|}
\hline Zooplankton & April & August \\
\hline Keratella & 0.18 & $\mathbf{0 . 0 3 8}$ \\
\hline Branchionus & & 0.77 \\
\hline Bosmina & & $\mathbf{0 . 0 2 4}$ \\
\hline Calanoid & & 0.123 \\
\hline Cyclopoid & & 0.668 \\
\hline Nauplii & $\mathbf{0 . 0 0 1}$ & $\mathbf{0 . 0 0 1}$ \\
\hline
\end{tabular}




\section{TABLE 5}

ANOVA Results for POC (months analyzed together). P-values in bold represent significant effects on response variables.

\begin{tabular}{|c|c|}
\hline Factor & $\mathrm{p}$-value \\
\hline Day & $<\mathbf{0 . 0 0 0 1}$ \\
\hline Month & 0.86 \\
\hline Cladocera & 0.32 \\
\hline Copepods & 0.97 \\
\hline Rotifers & 0.94 \\
\hline Velocity & $\mathbf{0 . 0 0 4 8}$ \\
\hline
\end{tabular}




\section{TABLE 6}

ANOVA Results for whole chlorophyll $\alpha$ (months analyzed together). $P$-values in bold represent significant effects on response variables.

\begin{tabular}{|c|c|}
\hline Factor & $\mathrm{p}$-value \\
\hline Month & $<\mathbf{0 . 0 0 0 1}$ \\
\hline Cladocera & 0.62 \\
\hline Copepods & 0.91 \\
\hline Rotifers ${ }^{*}$ Velocity & $\mathbf{0 . 0 1 3}$ \\
\hline Velocity & 0.48 \\
\hline Turbidity & 0.13 \\
\hline
\end{tabular}




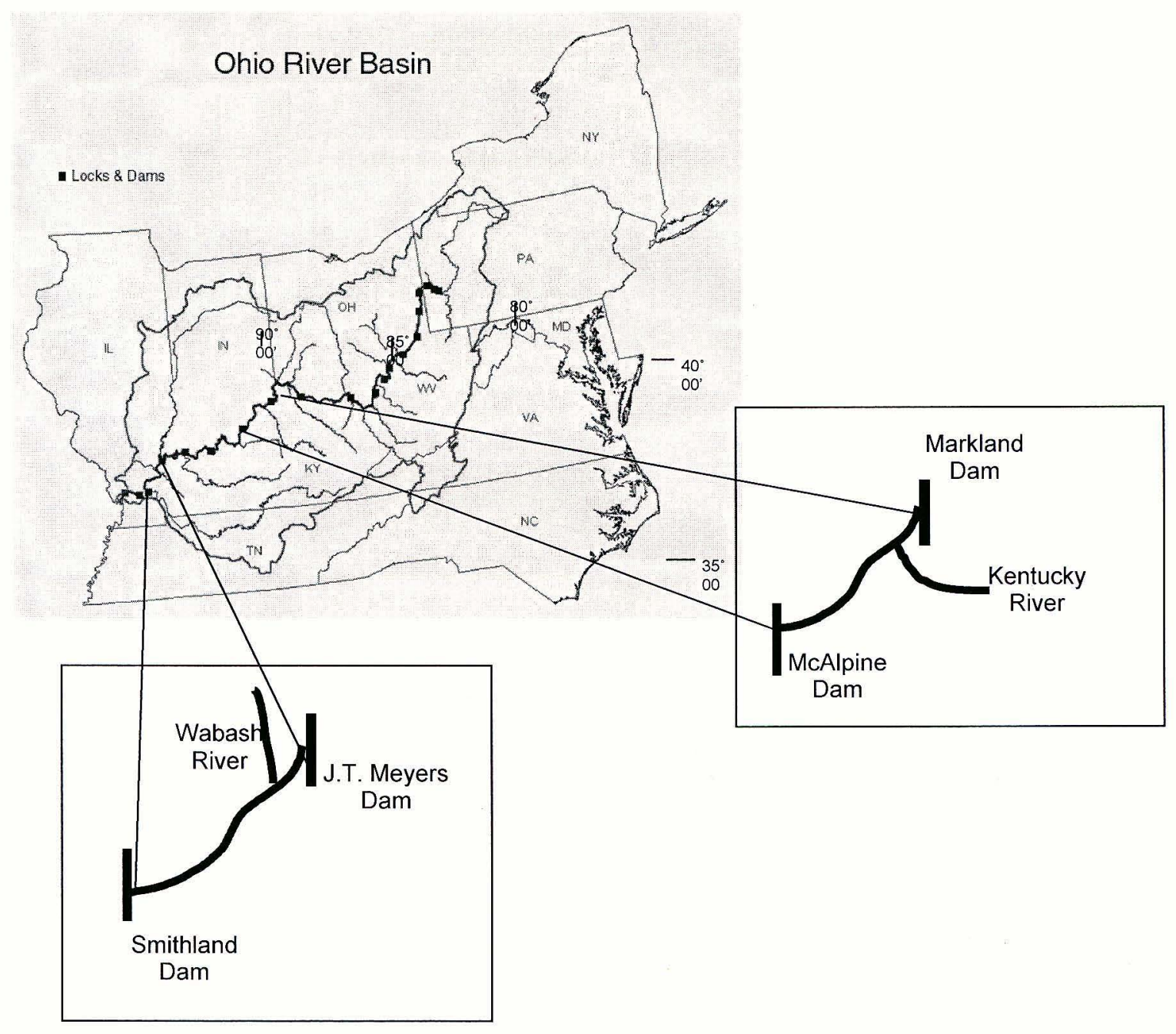

FIGURE 1

The Ohio River, McAlpine Pool (right inset), and the Smithland Pool (left inset), modified from Jack et al. 2002 

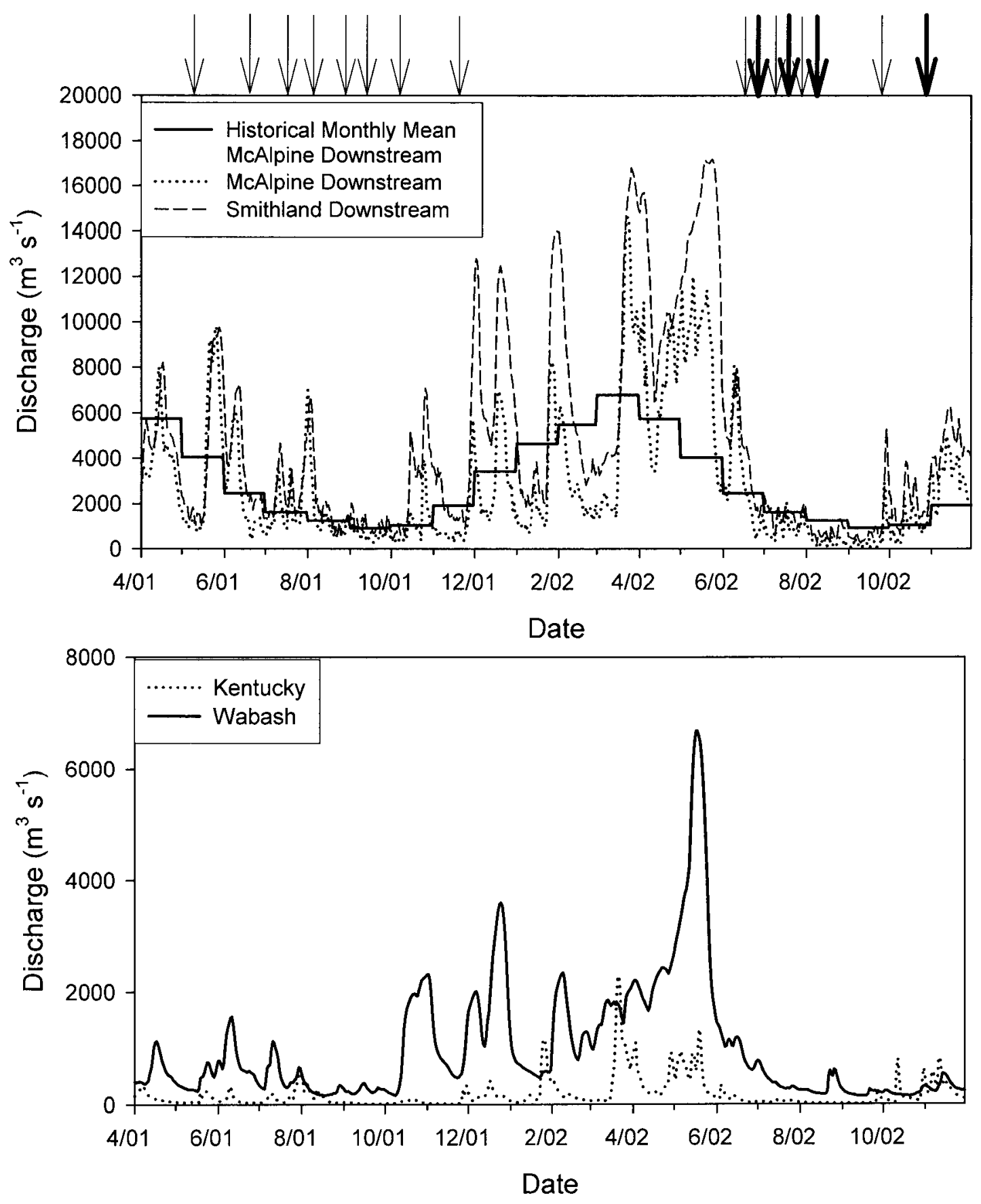

FIGURE 2

Daily mean discharge (USGS gauging stations) during study period for the McAlpine and Smithland Pools (top) and the Wabash and Kentucky Rivers (bottom). Light and dark arrows indicate the sample collection of the McAlpine and Smithland surveys respectively. Historical values represent the monthly means from 1929-2001. 

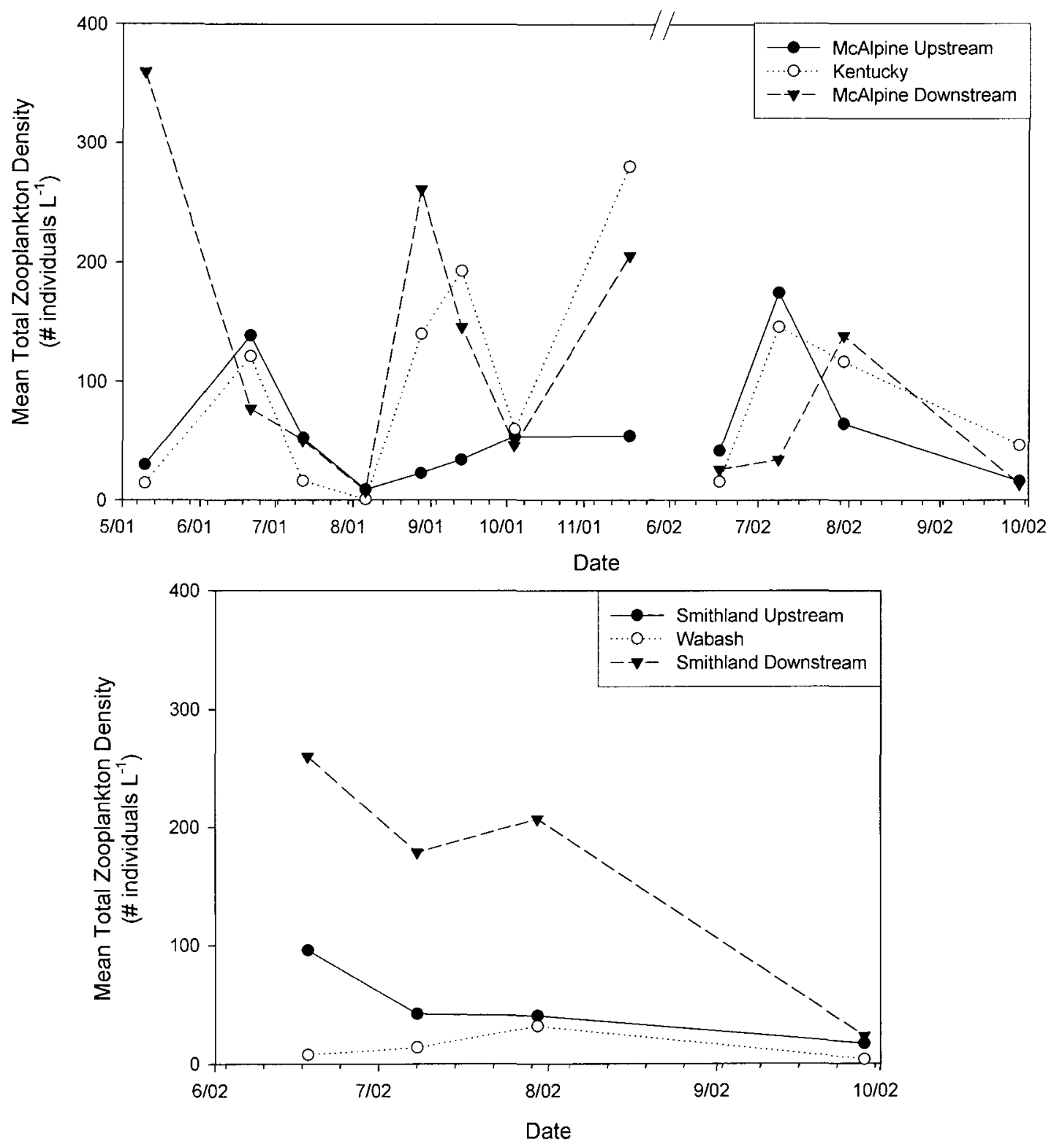

FIGURE 3

Mean total zooplankton density on sampling dates in 2001 and 2002. Double lines in the x-axis indicate a break in sampling dates between 2001 and 2002 for the McAlpine Pool and Kentucky River sites. 

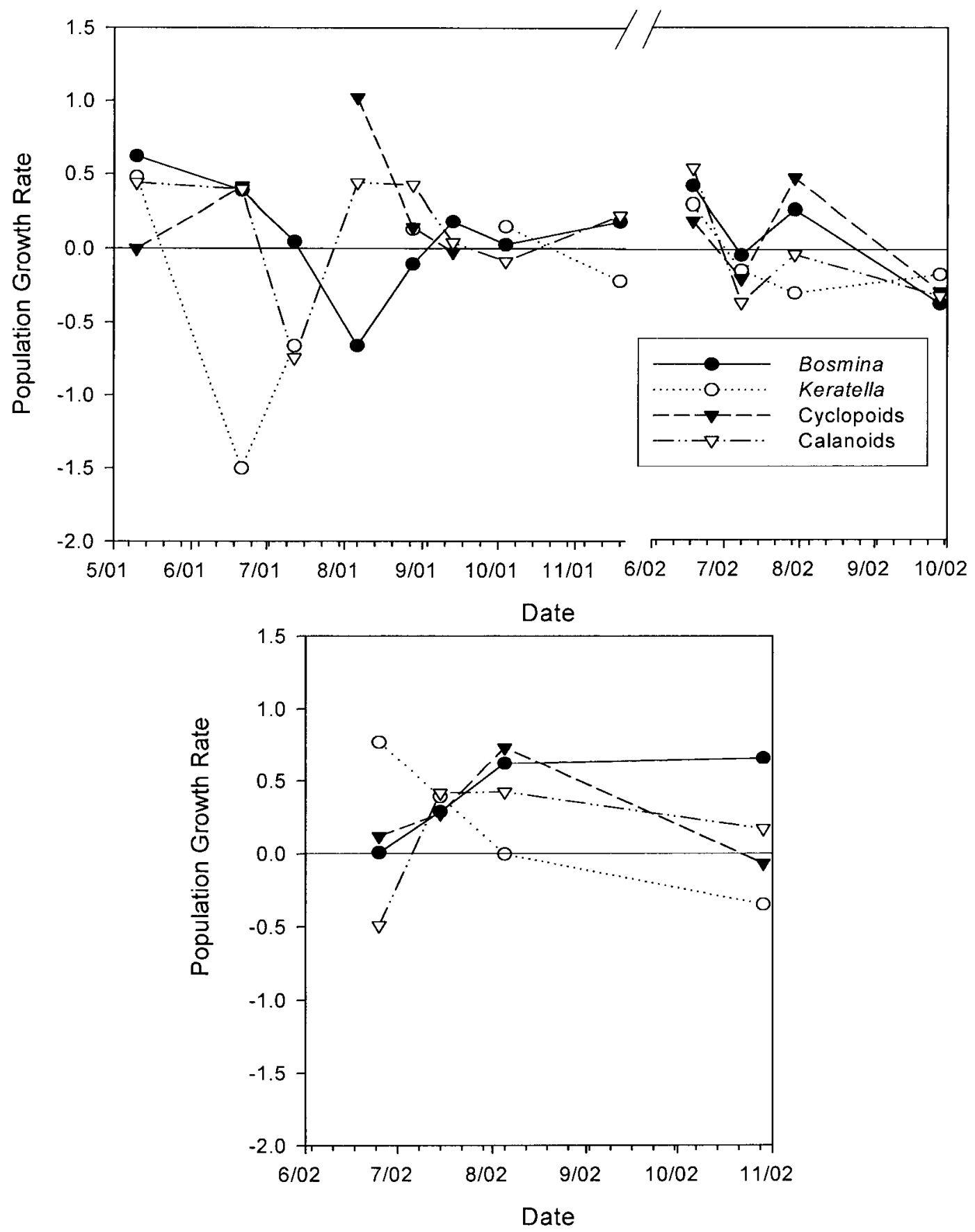

FIGURE 4

Daily zooplankton population growth rates in the McAlpine Pool (top) and the Smithland Pool (bottom). 

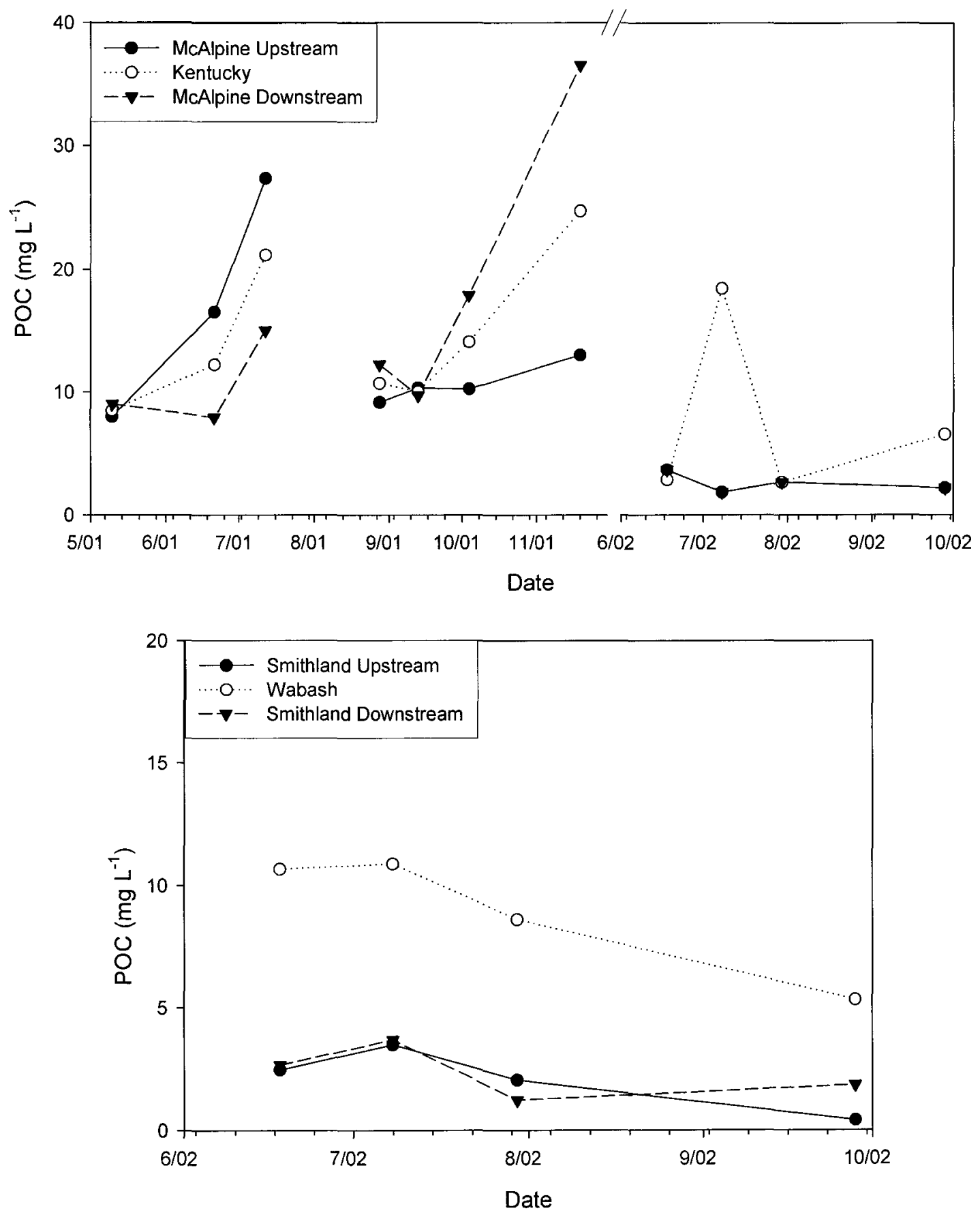

FIGURE 5

Particulate organic carbon in the upstream and downstream reaches of the Smithland and McAlpine Pools of the Ohio River and the Kentucky and Wabash Rivers. Double lines indicate a break in sampling dates between 2001 and 2002 for the McAlpine Pool and Kentucky River sites. 

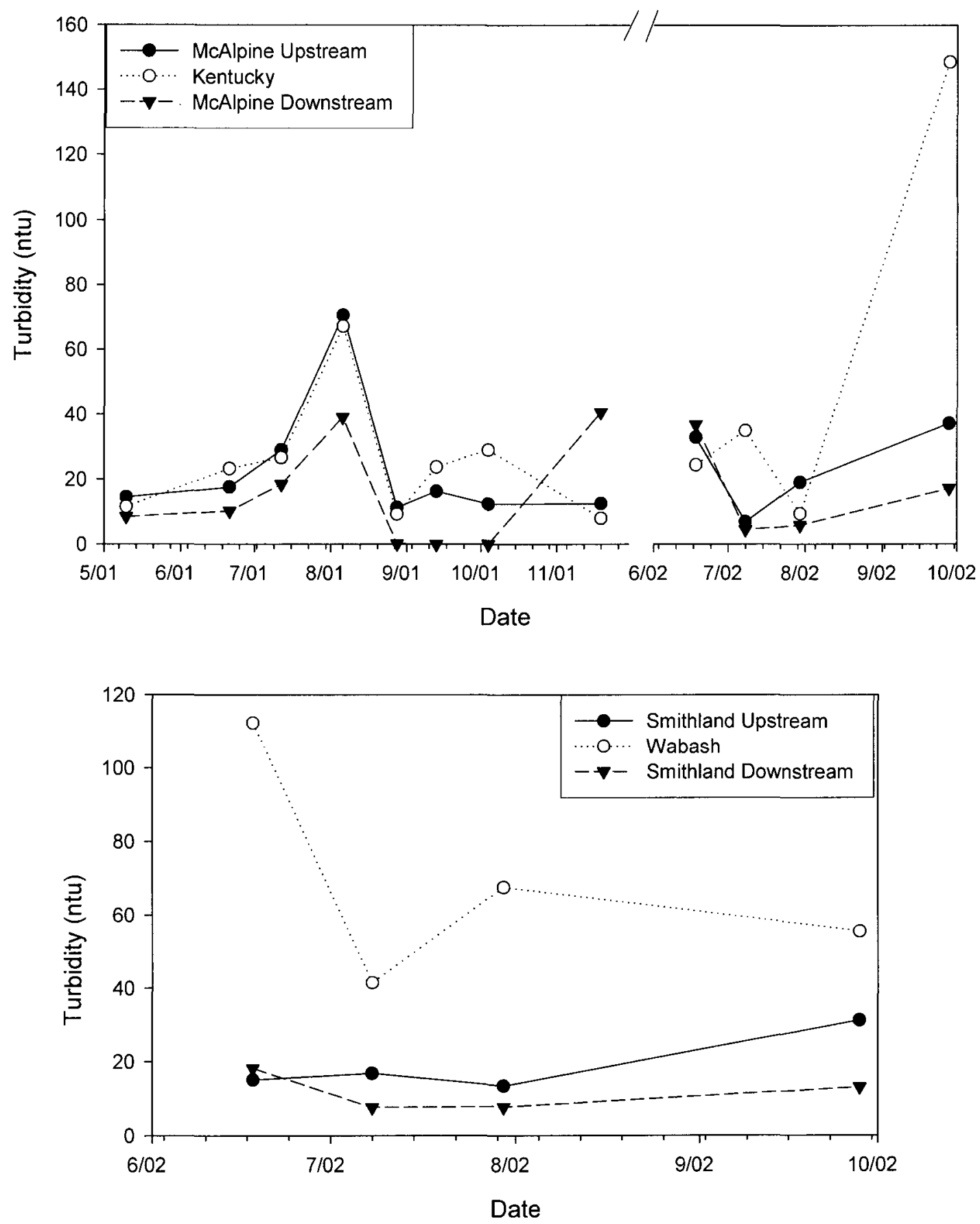

FIGURE 6

Turbidity in the upstream and downstream reaches of the Smithland and McAlpine Pools of the Ohio River and the Kentucky and Wabash Rivers. Double lines indicate a break in sampling dates between 2001 and 2002 for the McAlpine Pool and Kentucky River sites. 

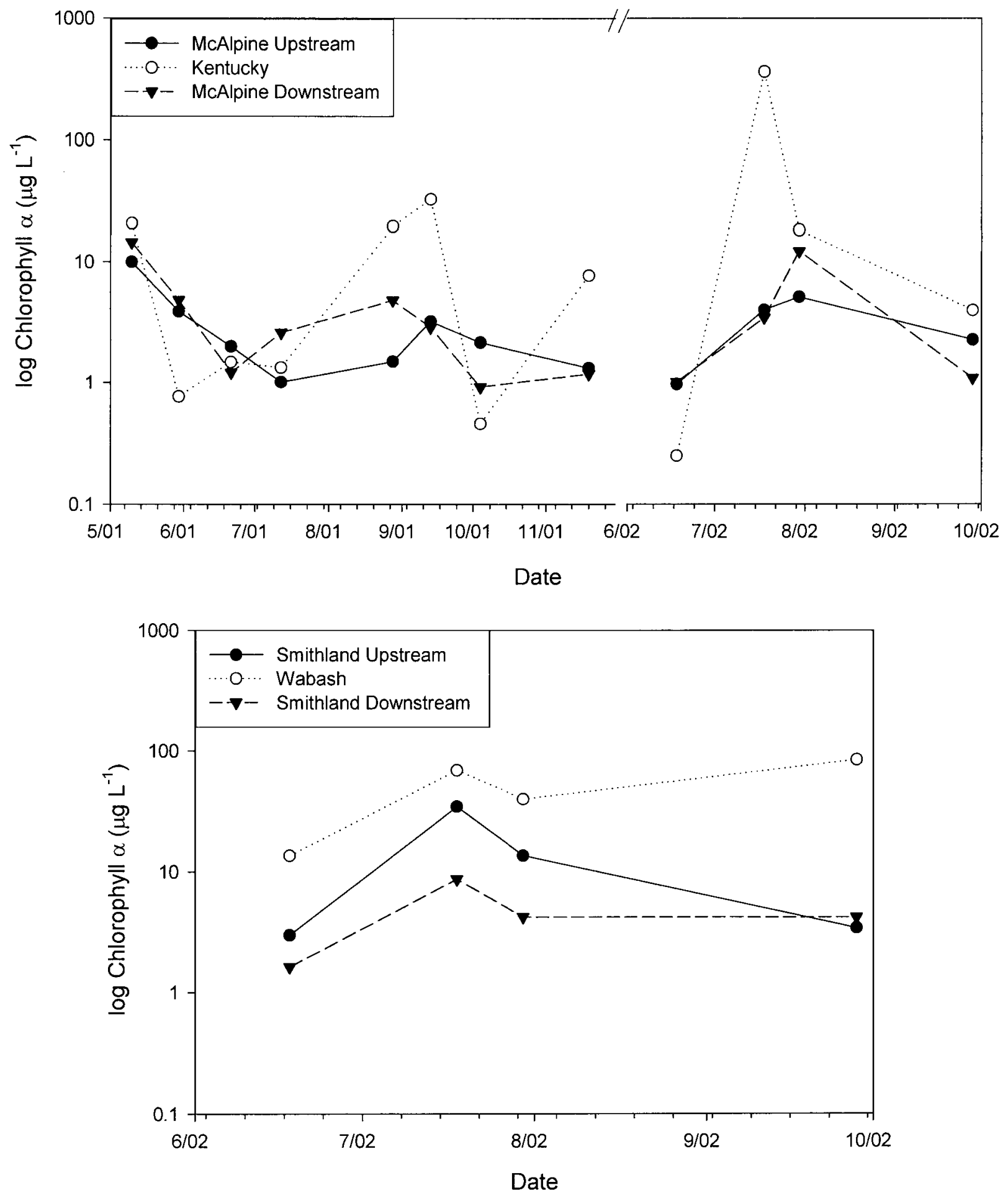

FIGURE 7

Chlorophyll $a$ in the upstream and downstream reaches of the Smithland and McAlpine Pools of the Ohio River and the Kentucky and Wabash Rivers. Double lines indicate a break in sampling dates between 2001 and 2002 for the McAlpine Pool and Kentucky River sites. Log axis used for clarity. 


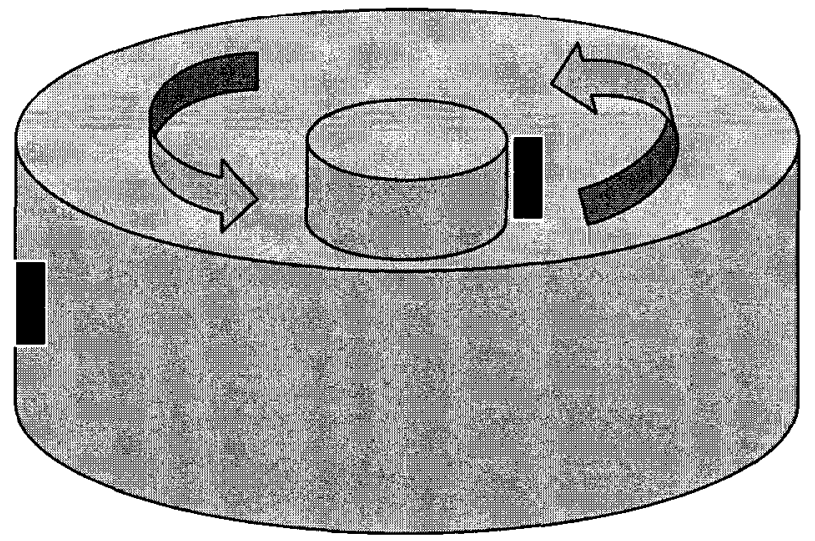

FIGURE 8

Tank design for mesocosm experiment. Black boxes represents a circulating pump, the cylinder represents a 55 gallon drum, and the arrow indicated the current direction. 


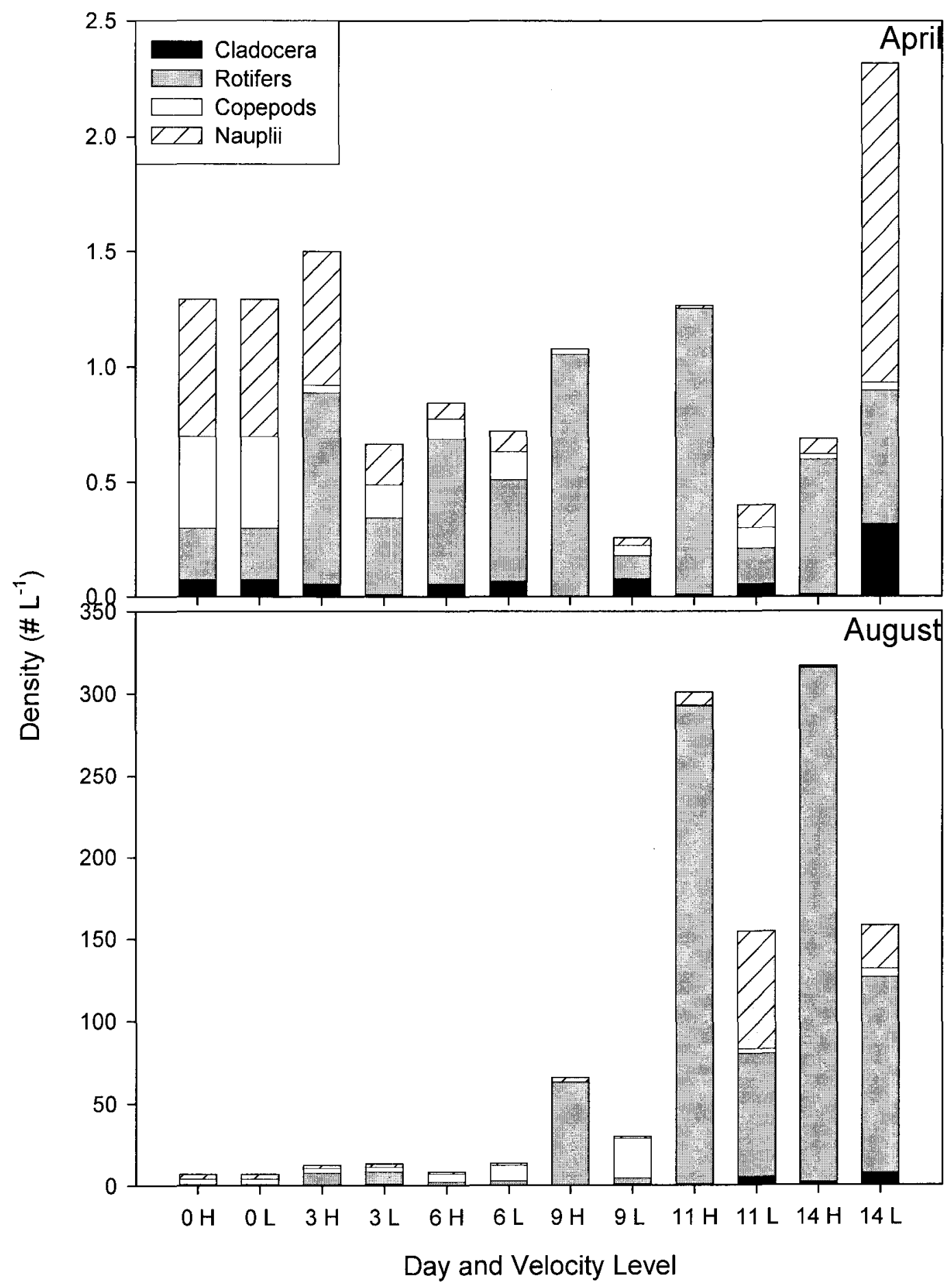

FIGURE 9

Species responses in April and August. $H$ and $L$ represent high and low velocity respectively. Note that $y$-axis range for April is two orders of magnitude smaller than for August. 


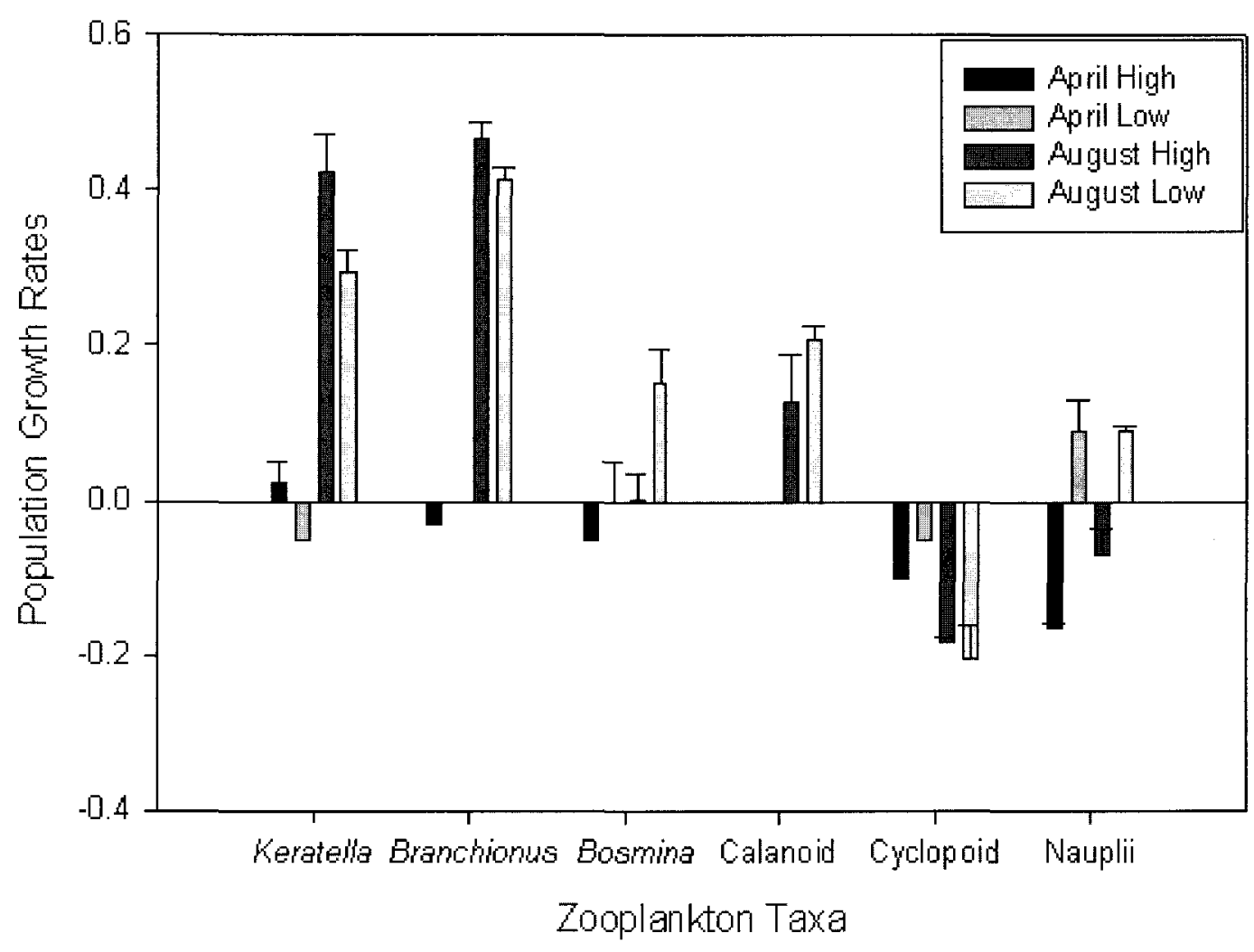

FIGURE 10

Population growth rates of dominant zooplankton taxa calculated over a 14 day period in the April and August in high and low velocity conditions. 


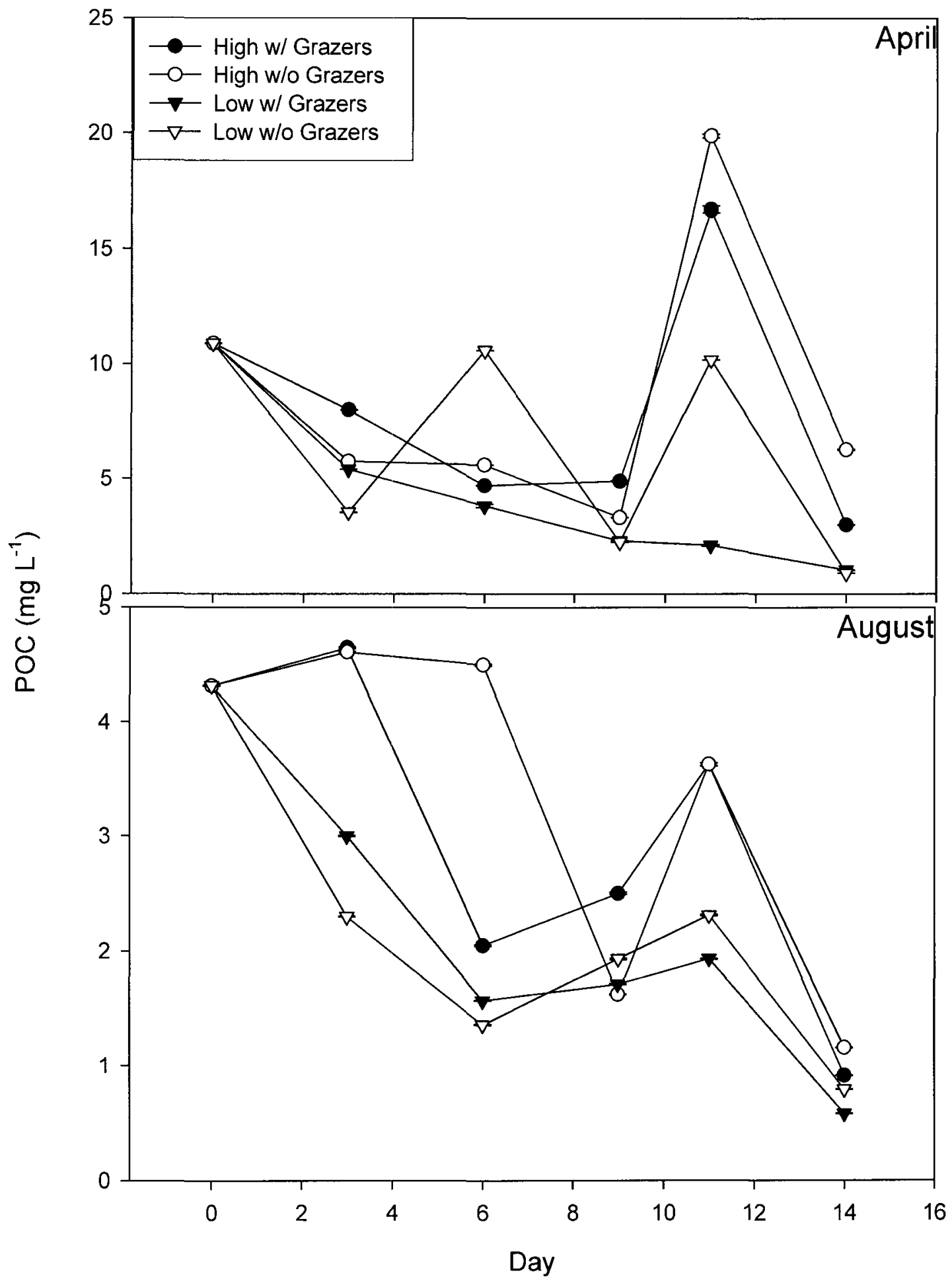

FIGURE 11

Particulate organic carbon (POC) in April and August. Note the difference between the $y$-axes. Bars represent standard error. 


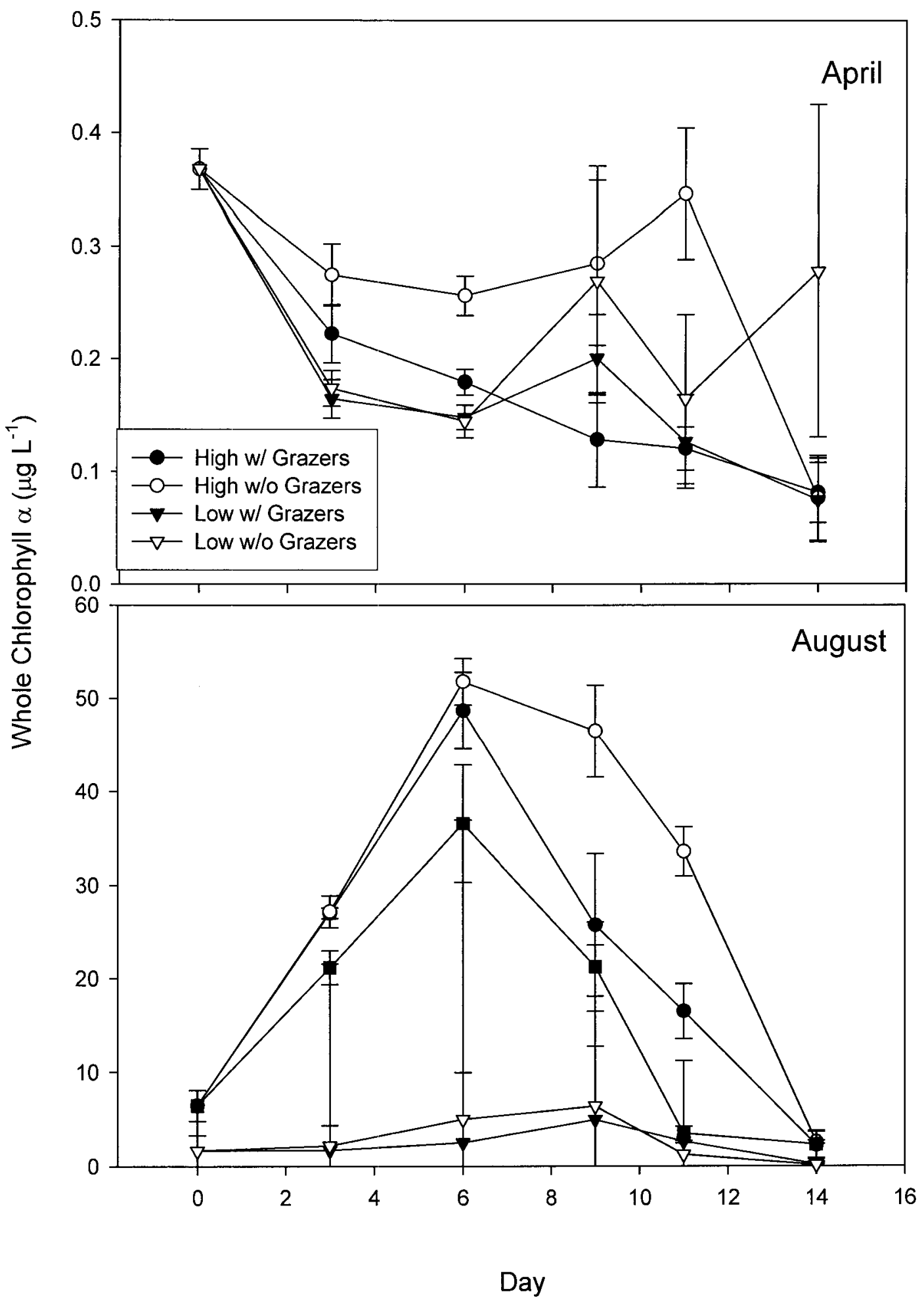

FIGURE 12

Whole chlorophyll $\alpha$ in April and August. Note the difference between the y-axes.

Bars represent standard error. 


\section{REFERENCES}

Acharya, K., Jack, J.D., Bukaveckas P.A. 2005. Dietary effects on life history traits of riverine Bosmina. Freshwater Biology, 50: 965-975.

Acharya, K., Bukaveckas P.A., Jack, J.D., Marcia Kyle, and James J. Elser. 2006. Consumer growth linked to diet and RNA - P stoichiometry: Response of Bosmina to variation in riverine food resources. Limnology and Oceanography, in press

Akopian, M., Garnier, J. and Pourriot, R. 1999. A large reservoir as a source of zooplankton for the river: structure of the population and influence of fish predation. Journal of Plankton Research, 21: 285-297.

Alcaraz, M., Saiz, E., and Calbet, A. 1994. Small-scale turbulence and zooplankton metabolism: Effects of turbulence on heartbeat rates of planktonic crustaceans. Limnoogy and Oceanography, 39: 1465-1470.

Alcaraz, M. 1994. Copepods under turbulence: grazing, behavior, and metabolic rates. Scientia Marina, 61(Supl. 1): 177-195.

Alcaraz, M., Saiz, E., Marrase, C., and Vaque, D. 1988. Effects of turbulence on the development of phytoplankton biomass and copepod populations in marine microcosms. Marine Ecology Progress Series, 49: 117-125.

American Public Health Association (APHA). 1985. Standard methods for the analysis of water and wastewater. $16^{\text {th }}$ ed. APHA, Washington, D.C.

Arar, E.J. and Collins, G.B. 1997. In vitro determination of chlorophyll $\alpha$ and pheophyton $\alpha$ in marine and freshwater physoplankton by fluorescence, p. 1-12. In Methods for the determination of chemical substances in marine and estuarine environmental samples. U.S. Environmental Protection Agency.

Baranyi, C., Hein, T., Holarek, C., Keckeis, S., and Schiemer, F. 2002 Zooplankton biomass and community structure in a Danube River floodplain system: effects of hydrology. Freshwater Biology, 47: 473-482. 
Basu, B.K. and Pick, F.R. 1996 Factors regulating phytoplankton and zooplankton development in temperate rivers. Limnology and Oceanography, 41: 1572-1577.

Basu, B.K. and Pick, F.R. 1997 Phytoplankton and zooplankton development in a lowland, temperate river. Journal of Plankton Research, 19: 237-253.

Basu, B.K., Kalff, J., and Pinel-Alloul, B. 2000. The influence of macrophyte beds on plankton communities and their export from fluvial lakes in the St. Lawrence River. Freshwater Biology, 45: 373-382.

Brinley, F.J. and Katzin, L.J. 1942. Distribution of stream plankton in the Ohio River system. American Naturalist 27:177-190.

Brooks, J.L. 1947. Turbulence as an environmental determinant of relative growth in Daphnia. Proceedings of the National Academy of Sciences 33: 141148.

Brown, A.V., Limbeck, R.L., Schram, M.D. 1989. Trophic importance of zooplankton in streams with alluvial riffle and pool geomorphology. Archiv fur Hydrobiologie, 1142: 349-367.

Bukaveckas P.A., Guelda D.L., Jack J.D., Koch R., Sellers T., Shostell J., 2005. Effects of point source loadings, sub-basin inputs and longitudinal variation in material retention on $\mathrm{C}, \mathrm{N}$ and $\mathrm{P}$ delivery from the Ohio River basin. Ecosystems, 8: $825-840$.

Bundy M.H., Vanderploeg H.A. 2002. Detection and capture of inert particles by calanoid copepods: the role of the feeding current. Journal of Plankton Research, 24: 215-223.

Burns, C.W., and Gilbert, J.J.1986. Direct observations of the mechanisms of interference between Daphnia and Keratella cochlearis. Limnology and Oceanography, 31:859-866.

Carpenter, S.R. 1996. Microcosm Experiments have Limited Relevance for Community and Ecosystem Ecology. Ecology, 77: 677-680.

Costello, J.H., Strickler, J.R., Marrasse, C., Trager, G., Zeller, R., Freise, A.J. 1990. Grazing in a Turbulent Environment: Behavioral response of a calanoid copepod, Cetrapages Hamatus. Proceedings of the National Academy of Sciences of the United States of America, 87:1648-1652.

DeMott, W.R., and Kerfoot, W.C. 1982. Competition among cladocerans: nature of the interaction between Bosmina and Daphnia . Ecology, 63:1949-1966. 
DeMott, W.R., Gulati, R.D., and Siewertsen, K. 1998. Effects of phosphorusdeficient diets on the carbon and phosphorus balance of Daphnia magna. Limnology and Oceanography, 43:1147-1161.

DeMott, W.R. and Gulati, R.D. 1999. Phosphorus limitation in Daphnia: Evidence from a long term study of three hypereutrophic Dutch lakes. Limnology and Oceanography, 44:1557-1564.

de Ruyter van Steveninck, E.D., Admiraal, W., and Van Zanten, B. 1990. Changes in plankton communities in regulated reaches of the lower River Rhine. Regulated Rivers: Research and Management, 5: 67-75.

de Ruyter van Steveninck, E.D., Admiraal, W., Breebaart, L., Tubbing, G.M.J. and Zanten, B. van. 1992. Plankton in the River Rhine: structural and functional changes observed during downstream transport. Journal of Plankton Research, 14:1351-1368.

Dirnberger, J.M., and Threlkeld, S.T. 1986. Advective effects of a reservoir flood on zooplankton abundance and dispersion. Freshwater Biology, 16: 387-396.

Dodson S.I., 1975. Predation rates of zooplankton in arctic ponds. Limnology and Oceanography, 20: 426-433.

Epp, R.W., and Lewis, W.M. 1984. Cost and speed of locomotion for rotifers. Oecologia, 61:289-292.

Gilbert, J.J. 1985a. Escape response of the rotifer Polyarthra: a high-speed cinematographic analysis. Oecologia (Berlin), 66: 322-331.

Gilbert, J.J. 1985b. Competition between rotifers and Daphnia. Ecology, 66: 1943-1950.

Gilbert, J.J., and R.S. Stemberger. 1985b. Prey capture in the rotifer Asplanchna girodi. Internationale Vereinigung fur theoretische und angewandte Limnologie, Verhandlungen, 22:2997-3000.

Guisan, A., T.C. Edwards, Jr., and T. Hastie. 2002. Generalized linear and generalized additive models in studies of species distributions: setting the scene. Ecological Modelling, 157:89-100.

Gosselain, V., Descy, J.P., Viroux, L., Joaquim-Justo, C., Hammer, A. Metens, A, and Schweitzer, S. 1998. Grazing by large river zooplankton: a key to summer potamoplankton decline? The case of the Meuse and Moselle rivers in 1994 and 1995. Hydrobiologia, 369: 199-216. 
Guelda, D. (2001) Source, Sink and Food Limitation of Ohio River Zooplankton. PhD Dissertation, University of Louisville, Louisville, Kentucky, USA

Guelda, D.L., R. W. Koch, J.D. Jack, P.A. Bukaveckas. 2005. Experimental evidence for food limitation and density-dependent effects on population growth rates of riverine zooplankton. River Research and Applications, 21:1-14.

Haney, J.F. and Hall, D.J. 1973. Sugar-coated Daphnia: A Preservation Technique for Cladocera. Limnology and Oceanography, 18: 331-333.

Hall, D.J., S.T. Threlkend, C.W. Burns, and P.H. Crowley. 1976. The sizeefficiency hypothesis and the size structure of zooplankton communities. Annuals Review of Ecology and Systematics, 7:177-208.

Hazelwood, D.H. 1966. Illumination and Turbulence Effects on Relative Growth in Daphnia Limnology and Oceanography, 11: 212-216.

Howarth R.W., Butler T., Lunde K., Swaney D., Chu C.R., 1993. Turbulence and planktonic nitrogen-fixation-a mesocosm experiment, Limnology and Oceanography, 38: 1696-1711.

Hynes, H.B.N. 1989. Keynote address, In; D.P. Dodge (ed.), Proceedings of the international large river symposium. Canadian Special Publication of Fiseries and Aquatic Sciences, 106: 5-10.

Jack, J.D., Wickham, S.A., Toalson, S., and Gilbert, J.J. 1993. The effects of clays on a freshwater plankton community: An enclosure experiment. Archiv fur Hydrobiologie, 127:257-270.

Jack J.D., Thorp J.H., 2000. Effects of the benthic suspension feeder Dreissena polymorpha on zooplankton in a large river. Freshwater Biology, 44: 569-579.

Jack, J.D. and Thorp, J.H. 2002. Impacts of fish predation on an Ohio River zooplankton community. Journal of Plankton Research, 24:119-127.

Jack, J.D., Sellers, T., and Bukaveckas, P.A. 2002. Algal production and trihalomethane formation potential: an experimental assessment and inter-river comparison. Canadian Journal of Fisheries and Aquatic Sciences, 59:14821491.

Jack, J. D., Fang, W., Thorp, J.H.. Vertical, lateral and longitudinal movement of zooplankton in a large river. Freshwater Biology, in press.

Jackson, D.C., Brown, A.V., and Davies, W.D. 1991. Zooplankton transport and diel drift in the Jordan Dam tailwater during a minimal flow regime. Rivers, 2:191-197. 
Junk, W.J., P.B. Bayley and Sparks, R.E. 1989. The flood-pulse concept in riverfloodplain systems. In: Dodge, D.P. (ed) Proceedings of the International Large River Symposium. Canadian Special Publication of Fisheries and Aquatic Sciences, 106: 89-109.

Keckeis, S., Baranyi, C., Hein, T., Holarek, C., Riedler, P, and Schiemer, F. 2003. The significance of zooplankton grazing in a floodplain system of the River Danube. Journal of Plankton Research, 25: 1-11.

Kim H-W, Hwang S-J, and Joo G-J. 2000. Zooplankton grazing on bacteria and phytoplankton in a regulated large river (Nakdong River, Korea). Journal of Plankton Research, 22: 1559-1577.

Kirk, K.L., and Gilbert, J.J. 1990. Suspended clay and the population dynamics of planktonic rotifers and cladocerans. Ecology, 71:1741-1755.

Kobayashi, T., Gibbs, P., Dixon, P.I. and Shiel, R.J. 1996 Grazing by a river zooplankton community: importance of microzooplankton. Marine and Freshwater Research, 47: 1025-36.

Kobayashi, T. 1997. Associations between environmental variables and zooplankton body masses in a regulated Australian river. Marine and Freshwater Research, 48: 523-529.

Koehl, M.A.R. and Strickler, J.R., 1981. Copepod feeding currents - food capture at low Reynolds' Number. Limnology and Oceanography, 26: 1062-1073.

Koste, W. 1978. Rotatoria. Gebruder Borntraeger. Berlin

Lampert, W. 1987a. Vertical migration of freshwater zooplankton: indirect effects of vertebrate predators on algal communities. Pages 291-299 in W.C. Kerfoot and $A$. Sih, editors. Predation: direct and indirect impacts on aquatic communities. University Press of New England, Hanover, New Hampshire

Lapesa S., Snell T.W., Fields D.M., et al. 2002. Predatory interactions between a cyclopoid copepod and three sibling rotifer species. Freshwater Biology, 47: 1685-1695.

MacKay, N.A. and Elser, J.J. 1998. Factors potentially preventing trophic cascades: Food quality, invertebrate predation, and their interaction. Limnology and Oceanography, 43: 339-347.

MacKenzie, B.R., Miller, T.J., Cyr, S., and Leggett, W.C. 1994 Evidence for a Dome-Shaped Relationship Between Turbulence and Larval Fish Ingestion Rates Limnology and Oceanography, 39: 1790-1799. 
Mallin, M.A. and Paerl, H.W. 1994. Planktonic Trophic Transfer in an Estuary: Seasonal, Diel, and Community Structure Effects. Ecology, 75: 2168-2184.

Marneffe Y, Descy J-P, and Thome J-P. 1996. The zooplankton of the lower river Meuse, Belgium: seasonal changes and impact of industrial and municipal discharges. Hydrobiologia, 319: 1-13.

Pace, M.I., Findlay, S.E.G. and Lints, D. 1992. Zooplankton in advective environments: the Hudson River community and a comparative analysis. Canadian Journal of Fisheries and Aquatic Sciences, 49:1060-1069.

Pennak R. 1989. Freshwater Invertebrates of the United States. Wiley Interscience. Canada

Peters R.H., Downing J.A., 1984. Empirical analysis of zooplankton filtering and feeding rates. Limnology and Oceanography, 29: 763-784.

Pillard, D.A. and Anderson, R.V. 1993. Longitudinal Variation in Zooplankton Populations in Pool 19, Upper Mississippi River. Journal of Freshwater Ecology, 8:127-132.

Plamann T, Maier G., Stich H.B. 1997. Predation impact of Cyclops vicinus on the rotifer community in Lake Constance in spring. Journal of Plankton Research, 19(8): 1069-1079.

Poff N.L., Allan J.D., Bain M.B., Karr J.R., Prestegaard K.L., Richter B.D., Sparks R.E., Stromberg J.C. 1997. The natural flow regime Bioscience, 47: 769-784.

Porter, K.F., Gerritsen, J. and Orcutt, J.D. Jr. 1982. The effect of food concentration on swimming patterns, feeding behavior, ingestion, assimilation, and respiration by Daphnia. Limnology and Oceanography, 27:935-949.

Porter, K.G. 1973. Selective grazing and differential digestion of algae by zooplankton. Nature (London), 244:179-180.

Porter, K.G., Y.S. Feig, and E.F. Vetter. 1983. Morphology, flow regimes, and filtering rates of Daphnia, Ceriodaphnia, and Bosmina fed natural bacteria. Oecologia, 58:156-163.

Pourriot, R., Rougier, C. and Mlquelis, A. 1997. Origin and development of river zooplankton: example of the Marne. Hydrobiologia, 345: 143-148.

Ramos-Rodriguez E, Conde-Porcuna JM. 2004. Impact of copepod predation on the fecundity of Keratella cochlearis (Rotifera). Archiv fur Hydrobiologie, 161:

541-552. 
Ray, L.L. 1974. Geomorphology and quaternary geology of the glaciated Ohio River valley: a reconnaissance study: a study of the geomorphic development and drainage modifications resulting from the Quaternary glaciations of the Ohio River valley, from above Cincinnati, Ohio, to Louisville, Ky. Geological survey professional paper 826 .

Reckendorfer W, Keckeis H, Winkler G, and Schiemer F. 1999. Zooplankton abundance in the River Danube, Austria, the significance of inshore retention. Freshwater Biology, 41: 583-591.

Richardson, W.B. 1992. Microcrustacea in flowing water: experimental analysis of washout times and a field test. Freshwater Biology, 28: 217-230.

Ridout, M.S., Demetrio, C.G.B. and Hinde, J.P. 1998. Models for counts data with many zeros. Proceedings of the XIXth International Biometric Conference, Cape Town, Invited Papers, pp. 179-192.

Rothhaupt, K.O. (1995) Algal nutrient limitation affects rotifer growth rate but not ingestion rate. Limnology and Oceanography, 40: 1201-1208.

Saiz, E., Alcaraz, M. and Paffenhofer, G.A. 1992. Effects of small-scale turbulence on feeding rate and gross-growth efficiency of three Acartia species (Copepoda: Calanoida). Journal of Plankton Research, 14:1085-1097.

Saiz, E. 1994. Observations of the free-swimming behaviour of Acartia tonsa; Effects of food concentration and turbulent water motion. Limnology and Oceanography, 39:1566-1578.

Saunders J.F., III and Lewis W.M., Jr.1988a. Zooplankton abundance and transport in a tropical white-water river. Hydrobiologia, 162: 147-155.

Saunders, J.F., III and Lewis, W.M., Jr 1988b. Zooplankton abundance in the Caura River, Venezuela. Biotropica, 20: 206-214.

Schiemer, F., Keckeis, H., Reckendorfer, W., and Winkler, G. 2001. The "inshore retention concept" and its significance for large rivers. Large Rivers, 12:509-516.

Sellers, T.W., 2001. Effects of water regulation on autochthonous production in a large river: A modeling and mass balance approach. Ph.D. Dissertation, 83 pages

Sellers, T.W. and Bukaveckas, P. 2003. Phytoplankton production in a large, regulated river: A modeling and mass balance assessment. Limnology and Oceanography, 48:1476-1487. 
Seuront, L., Yamazaki, H., Souissi, S. 2004. Hydrodynamic Disturbance and zooplankton Swimming Behaviour. Zoological Studies, 43:376-387.

Shiel, R.J., Walker, K.F., and Williams, W.D. 1982. Plankton of the Lower River Murray, South Australia. Australian Journal of Marine and Freshwater Research, 33:301-327.

Spaink, P.A., letswaart, T., and Roijackers, R. 1998. Plankton dynamics in a dead arm of the River Waal: a comparison with the main channel. Journal of Plankton Research, 20: 1997-2007.

Sterner, R.W., D.D. Hagemeier, W.L. Smith, and Smith, R.F. 1993.

Phytoplankton nutrient limitation and food quality for Daphnia. Limnology and Oceanography, 38:857-871.

Stricker, R.J. 1998. Observing free-swimming copepods mating. Philosophical Transactions of the Royal Society of London B., 353: 671-680.

Talling, J.F. and Rzoska, J. 1967. The Development of Plankton in Relation to Hydrological Regime in the Blue Nile. Journal of Ecology, 55: 637-662.

Tait, R.d., Shiel, R.J., and Koste, W. 1984. Structure and dynamics of zooplankton communities, Alligator Rivers Region, N.T., Australia. Hydrobiologia, 113:1-13.

Thorp, J.H. and Covich, A.P. editors. 1991. Ecology and Classification of North American Freshwater Invertebrates. Academic Press, New York

Thorp, J.H., Black, A.R., Haag, K.H. and Wehr, J.D. 1994. Zooplankton assemblages in the Ohio River: seasonal, tributary, and navigation dam effects. Canadian Journal of Fisheries and Aquatic Sciences, 51:1634-1643.

Thorp, J.H. and Delong, M.D. 1994. The riverine productivity model: an heuristic view of carbon sources and organic processing in large river ecosystems. Oikos, 70:305-308.

Thorp, J.H., Delong, M.D., Greenwood, K.S., Casper, A.F. 1998. Isotopic analysis of three food web theories in constricted and flood plain regions of a large river. Oecologia, 117:551-563.

Thorp, J.H., Casper, A.F. 2003. Importance of biotic interactions in large rivers: an experiment with planktivorous fish, Dreissenid mussels and zooplankton in the St. Lawrence River. River Research and Applications, 19:265-279. 
Threlkeld, S.T. 1986. Life table responses and population dynamics of four cladoceran zooplankton during a reservoir flood. Journal of Plankton Research, 8: 639-647.

VanZanten, B., Vandijik, G.M. 1994. Seasonal development of zooplankton of the lower river Rhine during the period 1987-1991. Water Science and Technology, 29: 49-51.

Vannote, R.L., Minshall, G.W., Cummins, K.E., Sedell, J.R., and Cushing, C.E. 1980. The river continuum concept. Canadian Journal of Fisheries and Aquatic Sciences, 37:130-137.

Viroux, L. 1997. Zooplankton development in two large lowland rivers, the Moselle (France) and the Meuse (Belgium), in 1993. Journal of Plankton Research, 19:1743-1762.

Viroux, L. 1999. Zooplankton distribution in flowing waters and its implications for sampling: case studies in the River Meuse (Belgium) and the River Moselle (France, Luxembourg). Journal of Plankton Research, 21:1231-1248.

Viroux, L. 2002. Seasonal and longitudinal aspects of microcrustacean (Cladocera Copepoda) dynamics in a lowland river. Journal of Plankton Research, 24:281-292.

Wallace, R. and Snell, T. Rotifera Pages 187-248 in J.H. Thorp and A.P. Covich, editors. Ecology and Classification of North American Freshwater Invertebrates. Academic Press, New York

Walks, D.J. and Cyr, H. 2004. Movement of plankton through lake-stream systems. Freshwater Biology, 49:745-759.

Ward, J.V. and Stanford, J.A. 1983. The serial discontinuity concept of lotic ecosystems. In Fontaine, T.D. and S.M. Bartell (Eds). Dynamics of Lotic Ecosystems. Ann Arbor Science, Ann Arbor, MI. pp. 29-42.

Wehr J.D., Thorp J.H., 1997. Effects of navigation dams, tributaries, and littoral zones on phytoplankton communities in the Ohio River. Canadian Journal of Fisheries and Aquatic Sciences, 54: 378-395.

Williams, L.G.1966. Dominant planktonic rotifers of the major waterways of the United States. Limnology and Oceanography, 11: 83-91.

Williamson, C. 1987. Predator-prey interactions between omnivorous Diaptomid Copepods and Rotifers: The role of prey morphology and behavior. Limnology and Oceanography, 32:167-177. 
Williamson, C. 1991. Copepoda Pages 787-822 in J.H. Thorp and A.P. Covich, editors. Ecology and Classification of North American Freshwater Invertebrates. Academic Press, New York

Yamazaki H., Squires K.D., 1996. Comparison of oceanic turbulence and copepod swimming. Marine Ecology Progress Series, 144: 299-301. 


\section{CURRICULUM VITAE}

Tamara Sluss

221 N. Clifton Ave. \#21

Louisville, KY 40206

tamarasluss@yahoo.com

\section{Education}

- M.S. Environmental Biology, University of Louisville December, 2003.

- B.S. Biology, University of Louisville 2000.

- Salutatorian, Fairview High School, Ashland, Kentucky 1996

\section{Professional Experience}

2005-present: Assistant Professor of Biology, Kentucky State University

2002-2004: Adjunct Faculty, Jefferson Community College

2004-2005: Full-time Faculty, Jefferson Community College

2004-2005: Research Associate, University of Louisville

2001-2004: University Fellow, University of Louisville

\section{Grants}

- Aquatic organisms in turbulent conditions: the effects of turbulence on the grazing rates of Copepods, Cladocera, Rotifers, and Zebra Mussel

Veligers. Kentucky Society of Natural History $\$ 600$; Kentucky Institute of the Environment and Sustainable Development $\$ 500$

- KY NSF EPSCoR Research Enhancement Grant: The effect of turbulence on food selection of Kentucky River Zooplankton. \$24,956.90, P.I.

- Comprehensive program to expose K-16 students, particularly underrepresented student populations, to natural resource and environmental education opportunities, USDA $\$ 200,000$, Co-PI

\section{Presentations}

- Kentucky Academy of Sciences (KAS), Murfreesboro, TN, November 2001.

- Ohio River Basin Consortium for Research and Education (ORBCRE), Louisville, KY, December, 2001. 
- Kentucky Water Resources Institute (KWRI), Lexington, KY, February, 2002.

- American Society of Limnology and Oceanography (ASLO), Victoria, B.C., Canada, June, 2002 and Savannah, GA, June, 2004.

- UK CEEB Spring Symposium May, 2006

\section{Service}

- Text book selection committee, Jefferson Community College

- President of the Biology Graduate Student Association, 2001-2003 (two terms). I regularly attended faculty meetings to represent issues facing graduate students.

- Academic Policies and Biology committees, Kentucky State University

- Salt River Watershed Watch biological and habitat assessment trainer 